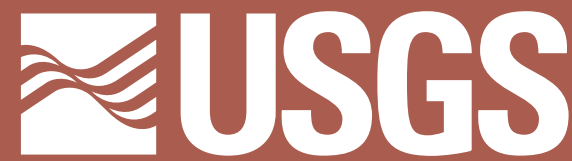

science for a changing world

\title{
The Human Factor in Mining Reclamation
}
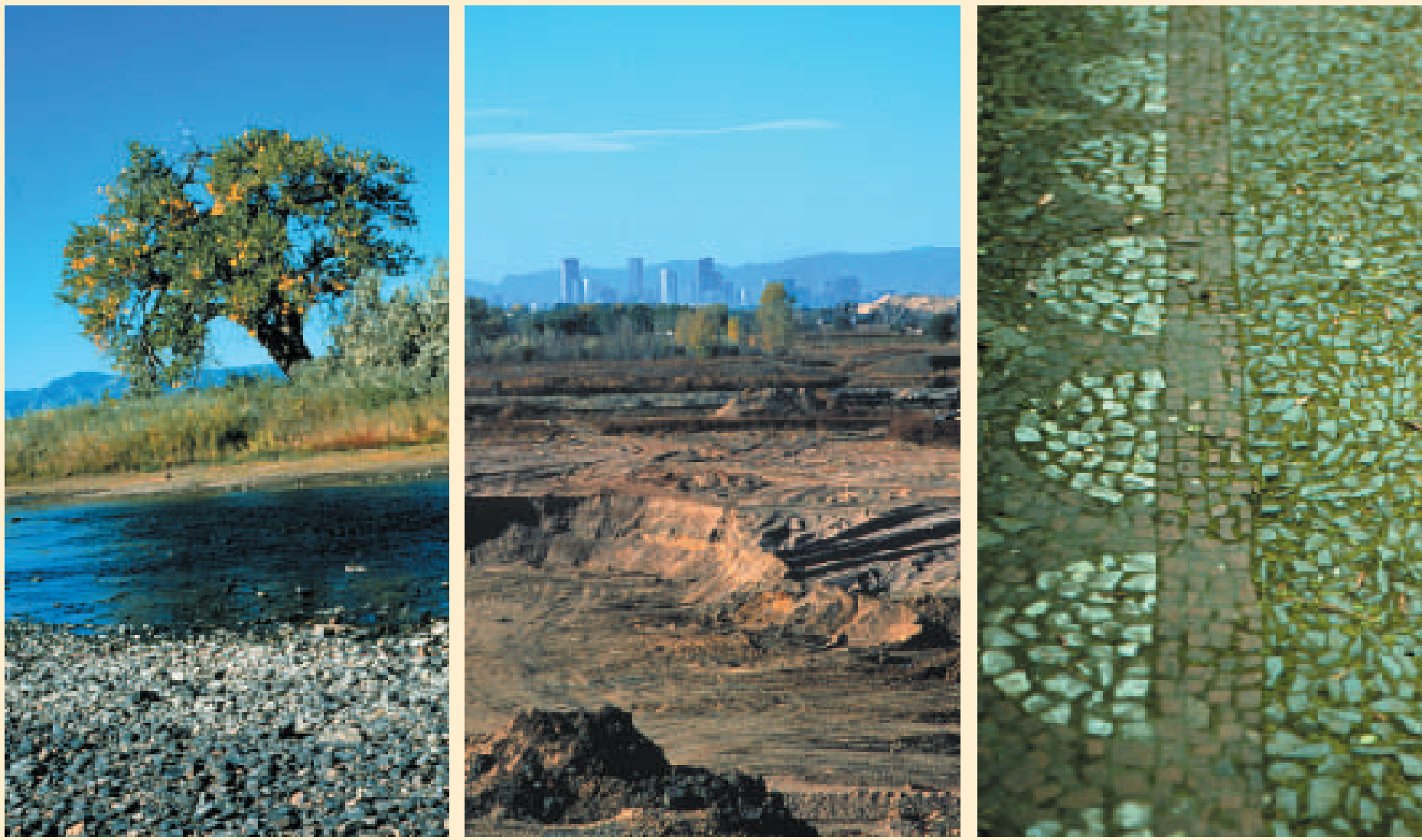

U.S. Geological Survey Circular 1191 
Cover. Photo credits: Left, South Platte Park, Littleton, Colo., photograph by Raymond Sperger. Center, City of Denver Skyline and Aggregate Industries, photograph by Jonathan Eady.

Right, Detail of stone paving design, photograph by B. Arbogast. 


\section{The Human Factor in Mining Reclamation}

By Belinda F. Arbogast, Daniel H. Knepper, Jr., and William H. Langer

U.S. Geological Survey Circular 1191

U.S. Department of the Interior

U.S. Geological Survey 


\section{U.S. Department of the Interior Bruce Babbitt, Secretary}

\section{U.S. Geological Survey \\ Charles G. Groat, Director}

First printing 2000

Free on application to U.S. Geological Survey, Information Services Box 25286, Federal Center

Denver, CO 80225

This report is also available on line at

http://greenwood.cr.usgs.gov/pub/circulars/c1191/

Any use of trade, product, or firm names in this publication

is for descriptive purposes only and does not

imply endorsement by the U.S. Government

\section{Library of Congress Cataloging-in-Publication Data}

Arbogast, B. F. (Belinda F.)

The human factor in mining reclamation / by Belinda F. Arbogast,

Daniel H. Knepper, Jr., and William H. Langer.

p. cm. - (U.S. Geological Survey circular ； 1191) Includes bibliographical references.

1. Abandoned mined lands reclamation. 2. Quarries and quarrying - Environmental

aspects. 3. Sand and gravel mines and mining-Environmental aspects. 4. Urbanization.

I. Knepper, Daniel H. II. Langer, William H. III. Title. IV. Series.

TD195.03 A73 2000

$333.76^{\prime} 5153-\mathrm{dc} 21$

Photo composition by William E. Sowers 


\section{Contents}

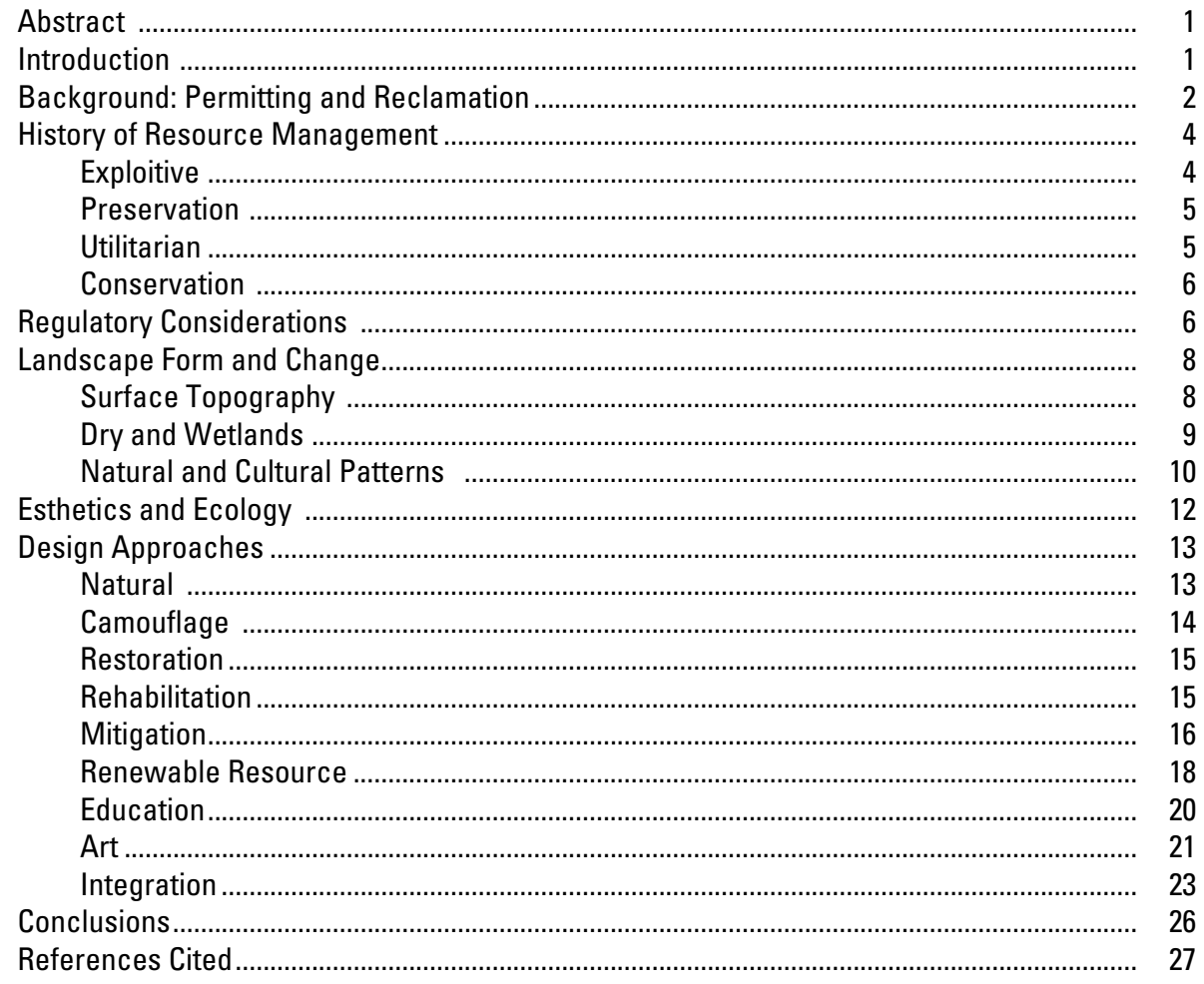

\section{Figures}

1. Stylized oblique aerial view, 3-D illustration of Colorado Front Range ..........................

2-28. Photographic images showing:

2. Examples of recent or current construction in the

Urban Front Range area, Colorado

3. Rock features exposed by mining and road construction, Colorado Front Range ................................................................................... 7

4. “Earthworks for Hillside Housing," near Los Angeles, Calif........................... 8

5. Geometric landforms produced by humans and by geologic processes....... 8 
6. Ryoan-ji, circa 1488-99; within the Daiju-in monastery,

Kyoto, Japan .......................................................................................... 11

7. “I am Sorry," 1995; sand, gravel, and 1,000 cement balls ............................... 11

8. "Wheat Fields on Tablelands Cut by the Marias River,"

Cutbank, Mont.

9. Cottonwood and willow restoration in a mined-out sand and gravel pit, Fort Collins, Colo............................................................................................ 14

10. Vehicular entrance to a mining facility............................................................ 14

11. View west from within the WREN pit, east-central Fort Collins, Colo.............. 15

12. Before and after aspects of Butchart Gardens, Vancouver Island, B.C......... 16

13. Quarry at Weldon Springs, Mo............................................................... 17

14. South Platte Park, Colo., formerly an aggregate mining site .......................... 18

15. Restored wetlands from gravel mine site, Boulder Valley, Colo. ..................... 18

16. Sandstone fountain and pool in Hillsboro, Oreg., constructed of old building foundations and lintels ............................................................ 19

17. Recycled asphalt available for other projects (Recycled Materials Co.)....... 19

18. Stockpile at Western Mobile Boulder's Glass Crushing Center....................... 19

19. NSA/ASLA Student Competition First Place: Linda Attaway, Mary Dewing, University of Colorado at Denver.....

20. Complex vegetation of the Minnesota prairie 21

21. Western Mobile's xeriscape garden in Albuquerque, N.Mex ............................ 22

22. Parc des Buttes-Chaumont, Paris.................................................................. 22

23. Aexoni Quarry, Greece .................................................................................. 23

24. "Broken Circle" ................................................................................................. 23

25. "Untitled (Johnson Pit \#30)" ............................................................................... 24

26. Coloring book page with theme of "working in partnership to achieve balanced natural resource management" ......................................... 25

27. Quarry Cove, Yaquina Head Outstanding Natural Area, Newport, Oreg........ 25

28. Water strider earthen sculpture from "Effigy Tumuli" 1983-85...................... 26

\section{Tables}

1. Construction mine (including sand and gravel, hard rock) permits for 1992-1997, Colorado Urban Front Range

2. Types of after-use for mines located below (wet bottoms) or above (dry bottoms) the water table.

3. Natural patterns of hard rock (quarry) and sand and gravel (pit) mines in the U.S. 10

4. Design approaches to reclaiming mine sites 


\title{
The Human Factor in Mining Reclamation
}

\author{
By Belinda F. Arbogast, Daniel H. Knepper, Jr., and William H. Langer
}

\begin{abstract}
Rapid urbanization of the landscape results in less space available for wildlife habitat, agriculture, and recreation. Mineral resources (especially nonmetallic construction materials) become unrecoverable due to inaccessibility caused by development. Few commercial or residential buildings are razed to make way for greenbelts or to gain access to aggregate for construction. The task of obtaining mineral commodities in a developed urban site is politically charged, and inefficient, not to mention expensive. Demand increases for the production of construction materials, including sand and gravel, crushed stone, dimension stone, and clay, whereas economical recoverable reserves of stone are covered by urban encroachment or made off-limits by open space. The remaining viable aggregate resources are in many instances not permitted due to vocal opposition from neighboring citizens. Mineral extraction does alter the landscape and is largely perceived as harmful to the environment. However, closing off access to a resource does not reduce the demand; neither does it prevent changes in ecosystems.
\end{abstract}

This review of the literature for actual and proposed reclaimed mine sites may enable land planners, industry, and the public to recognize that innovative designs exist in both past and present. Although some mine sites with serious problems are described herein, attention needs to be drawn to thoughtful reclamation projects for better future management. The human perception of mining can bring about possible confusion from a historic perspective, with regards to regulation, and from varying definitions of landscape. Selected sites in this report provide information in terms of their history, landform, design approach, and visual discernment. Examples from Colorado are included as a jumping-off place for the broader issue of regions soundly developing mining sites, permitting the best utilization of natural resources, and respecting the landscape. Only in seeing and recognizing our own visual prejudices can we hope to evaluate land-use issues wisely.

\section{Introduction}

The Front Range Infrastructure Resources Project is a 5-year effort of the U.S. Geological Survey to acquire, interpret, and disseminate information about the location and characteristics of infrastructure resources. One task of the initial study is to identify past and current landscape practices in hard rock and aggregate resource development and reclamation, particularly for the

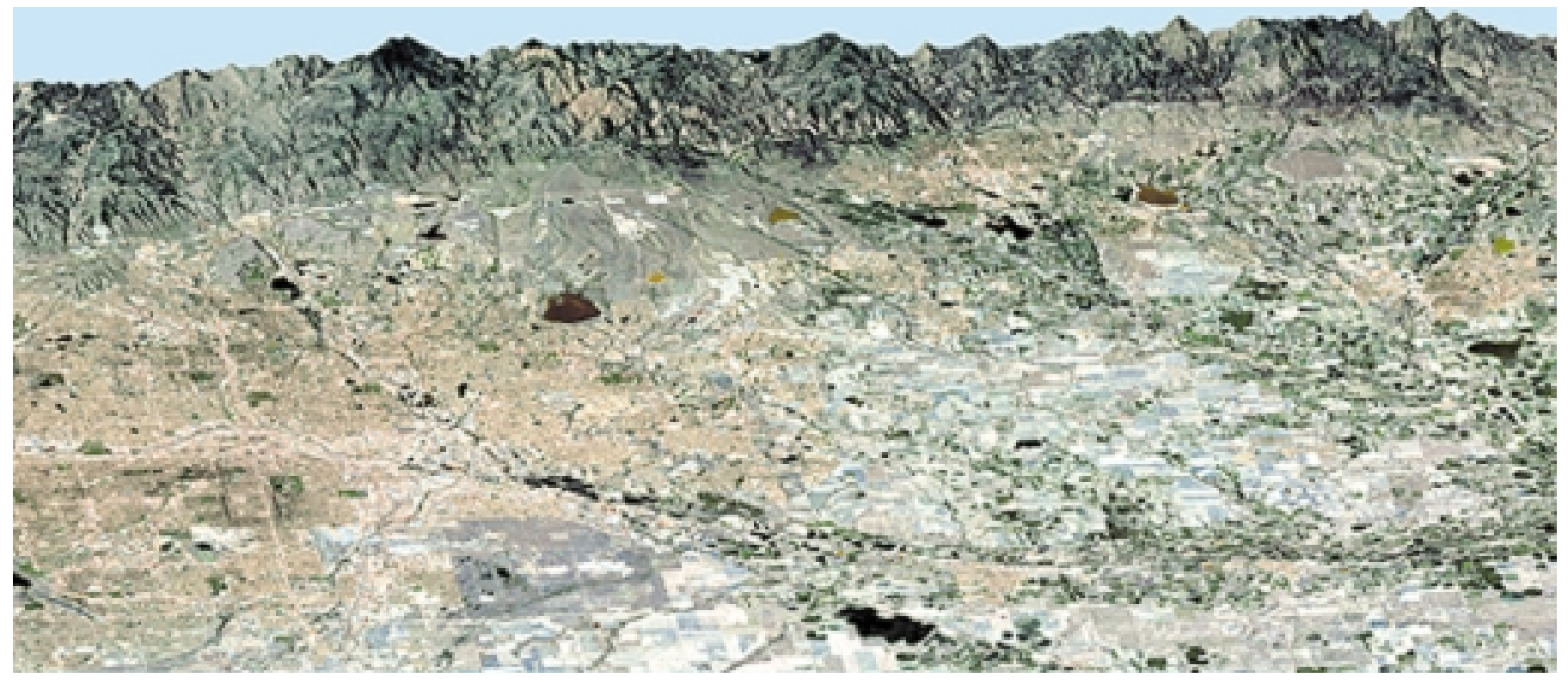

Figure 1. Stylized oblique aerial view, 3-D illustration of Colorado Front Range. Image by D. Knepper, Jr. 
Colorado Front Range urban corridor. A need to study regional development and the changing nature of mining reclamation was also identified. This report attempts to show that Colorado's experience in dealing with mining effects is not unique, and that potential problems and solutions are universal in scope.

People want affordable homes and new schools, green lawns, more and improved roads, cheap and abundant fuel, and convenient shopping. Many of those same people do not want natural aggregate mines, dams to collect and store water, more drilling rigs, and uncontrolled growth. Conflict is inevitable and outwardly irreconcilable: material things that people desire cannot be provided without the undesirable processes that produce them. However, with careful resource management, many undesirable processes can be eliminated or minimized. This report describes the dilemma of the desire for everything green and pretty coupled with the demand for all the modern conveniences.

The growing human population uses more and more mineral resources for industries ranging from agriculture and commerce to residential housing and recreation. The effect of these human enterprises is to constantly change the landscape. Political, economic, and esthetic influences vary over time, causing complex, frequently not understood, pressure on the aggregate industry, land-use planners, and Earth's ecosystems. In the State of Colorado, planners say that new residents will triple the population of the Colorado Plains over the next decade (fig. 1). State growth (Colorado's population reached 4 million people in 1998, about 3.2 million people live along the Front Range) is a concern for most residents (Sanko, 1997) and county commissioners. Many residents support stronger State laws to prevent urban sprawl and preserve wildlife habitat (Morson, 1997). One research group claims that Colorado communities pay more for population growth and services than they earn from new resident taxes. Thus, tax revenues cannot cover the expenses for basic infrastructure such as schools, sewer service, fire protection, and recreation facilities (Brinkley, 1997a). Denver International Airport and the new Interstate E-470 tollway may bring employment, demands for housing, and business to Colorado's Front Range area; but growth comes with a price for water, land, and wildlife.

This report examines that part of the problem that deals with extraction, processing, and reclamation in the aggregate industry, and how this essential activity can coexist with continued public pressure to restrict it, while still meeting product demands issued by the same public. An important aspect is the reclamation of extraction and processing sites - turning undesirable features (quarries and pits) into something perceived as desirable by the public (reservoirs, recreation sites, for example). Examining past approaches to mining and reclamation may help to identify those factors that contribute both positively and negatively to reclamation projects considered ultimately successful and to the public perception of the aggregate industry as a whole.

\section{Background: Permitting and Regulation}

In recent years, some rock product journals report fewer new mining permits being granted by urban counties. One article pointed out Jefferson County, Colo., as consistently denying new aggregate mining permit applications from the period 1982 to 1989 (Carter, 1989). Karen Berry, currently (1999) with the
Jefferson County Planning Department, has stated that mining permits are assessed on a case-by-case basis and examined sitespecific for allowable use. Her further comment was that more construction material mines are approved than denied and that some permits are withdrawn by the applicant. Since 1989 at least six applications have been approved, including two sand and gravel pits permitted in 1996 that totaled more than 1,000 acres. It is new, large hard rock quarries that tend to be disapproved in Jefferson County, although some existing operations have been granted amendments to enlarge. Remarkably little specific information is available from some Colorado urban county planning departments, making it difficult to accurately quantify precise operation types. Table 1 gives the summary of applications, county by county, in the Colorado Urban Front Range area.

Table 1. Construction mine (including sand and gravel, hard rock) permits for 1992-1997, Colorado Urban Front Range.

\begin{tabular}{lccc}
\hline Counties & Application & Approved & Denied \\
\hline Adams & 8 & 7 & 1 \\
Arapahoe & 2 & 2 & 0 \\
Boulder* & 9 & 6 & 0 \\
Denver** & 1 & 1 & 0 \\
Douglas & 3 & 2 & 1 \\
Jefferson & 3 & 3 & 0 \\
Larimer & 12 & 11 & 1 \\
Weld*** & - & - & - \\
Total & $\overline{3}$ & $\overline{32}$ & $\overline{3}$ \\
\hline
\end{tabular}

* Two special use reviews are in progress, and one has been withdrawn.

** Denver city limits are the same as the county. No permits have been issued since 1956 with one exception. Due to a prior mineral agreement with Adams County, operator approval was granted when land was annexed for Denver International Airport.

*** County Planning Services would not release information.

The importance of operator credibility cannot be underestimated in the mine approval process. Mining is negatively perceived when a local news headline reads, "Broken vow the pits to neighbors of Boulder [Colo.] mine" (Finley, 1997). The apparent lack of communication between the original land owners (Flatirons Sand and Gravel) and the community led to a neighborhood outcry when an approved restoration plan was legally altered with the knowledge and approval of government agencies, years after the original approval. The National Stone Association " $* * *$ encourages its members to work with community leaders and citizen groups in developing plans for appropriate uses of the land in the community interest $* * *$ " (1995, p. POLICY-9). Flatirons Sand and Gravel ended up with a potential public relations problem for the industry: the mining company had won an environmental award and 1 year later was in the news because neighborhood citizens felt betrayed by a change in land development plans.

Public perception of nature and culture has led to an inconsistent approach to mined land reclamation. The Western United States mindset of not wanting Federal government interference plus a mistrust of bureaucracy has a role in the lack of cohesive land planning by individual competitive cities and counties. As a society, North Americans become angered by an aggregate pit in their neighborhood but find an 1880's wooden mine shaft in the 
mountains quaint and photogenic. We argue against the production of sand and gravel yet make use of new shopping malls and parking lots, and want additional freeway lanes (fig. 2). Forty thousand major shopping malls line U.S. highways and 10 thousand sand and gravel pits are a major ingredient in supporting the country's infrastructure. The U.S. total averages about 10 tons of aggregate per capita per year consumption, with sand and gravel production alone valued at $\$ 4.8$ billion in 1997 (U.S. Geological Survey, 1997, p. 6). County commissioners hear arguments (including the proximity of open space land or inconsistency with historic land use and zoning) against the permitting of mineral mines. Some people tend to believe "open space" is undisturbed, in its natural condition, when in reality it is merely undeveloped areas of land and water. Mining is an interim land use with successful reclamation resulting in a stable postmining landscape. Society thinks it is being environmentally responsible by denying permits to mine, recycling newspapers, and recycling plastic, yet immense amounts of water are consumed, grass clippings are put in plastic bags for refuse pickup, and construction demands continue to increase.

In the 1960's, Peter Blake brought attention to the deterioration of America's landscape. He quoted an acquaintance as saying, "The national purpose of the United States, from the very beginning, has been to let everyone make as much money as he possibly can. If they found oil under St. Patrick's Cathedral, they would put a derrick smack in the center of the nave" (1979, p. 23). Things have changed since the 1960's. The public might take issue with geologic exploration under a church, but in less clearly defined situations it takes vision and research to protect the environment and provide infrastructure resources.

Perhaps it is in our mass communications that messages to the public can become muddled. An environmental group reports, "The federal office in charge of policing strip mines has been so derelict in its responsibilities that almost none of the 120,000 acres strip-mined in Colorado has been reclaimed $* * *$ " (Brinkley, 1997b). A reader may easily overlook the word "coal" halfway through Brinkley's article and assume that most mines in Colorado have not been fully reclaimed. One needs to distinguish between surface mining (open pit, strip, or dredging) and underground mining operations, define what constitutes reclamation, and understand how various laws regulate different commodities. Newspapers cover complex issues and ideas in a small amount of space, at times in as little as 25 words or less. The journalist is usually a nonscientist trying very hard to come up to speed on a myriad of studies, determine credibility, and report in layperson terms.
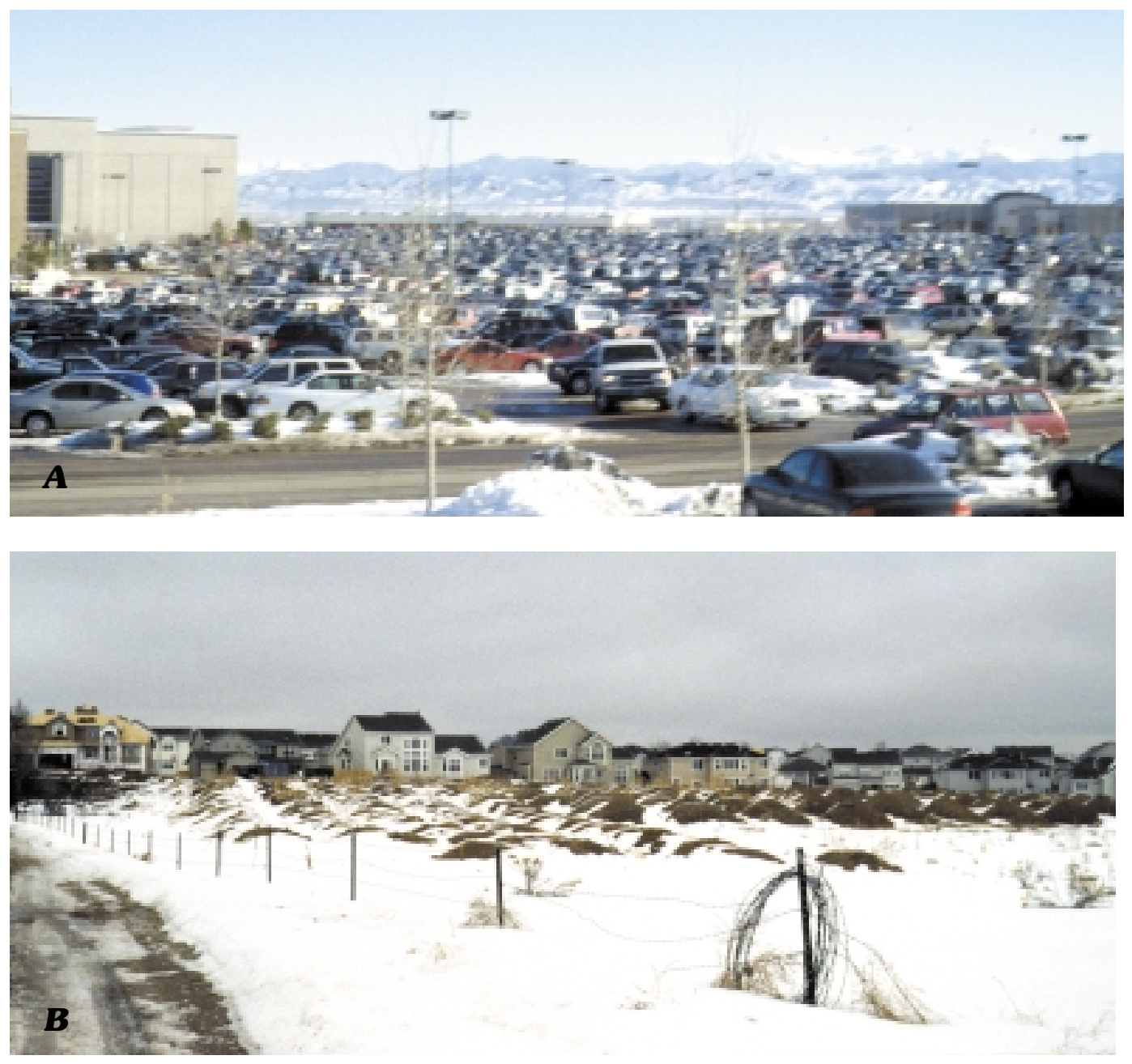

Figure 2. Examples of recent or current construction in the Urban Front Range area, Colorado. $A$, Parking lot at south end of Park Meadows Mall, Colo. B, Suburban home construction in Arapahoe County, Colo. Photographs by B. Arbogast. 
Just over 20 years ago, Congress passed the Surface Mining Control and Reclamation Act in 1977. The Act requires coal mining companies to restore all surface-mined land to its premining condition; however, no specific Federal legislation requires such reclamation for minerals. "According to the Bureau of Mines, between 1930 and 1980 only 8 percent of the land mined for metals and only 27 percent of the land mined for minerals was reclaimed" (Owen and Chiras, 1995, p. 504). The Bureau went on to report that 75 percent of the land mined for coal was reclaimed. Who is correct - the now-defunct Bureau, the environmental group, or both? How much of that land is still actively permitted? The Colorado Department of Natural Resources lists 17 active coal and 377 sand, gravel, and aggregate mines (Hemborg, 1996) producing approximately 26 million and 40 million tons respectively (Cappa and Tremain, 1995). Two-thirds of the coal in Colorado is mined underground, whereas most aggregate is extracted aboveground. A reporter, reader, or taxpayer can find it easy to confuse the issues, be misled by statistics, and lump all mining together. In order to better understand past mining approaches, this report examines four resource management practices.

\section{History of Resource Management}

For the last 200 years, four resource management approaches have been employed in the United States (Owen and Chiras, 1995): exploitive, preservation, utilitarian, and conservation. Whether the focus is on farming, rangeland, forestry, or mining, land-use approaches have been historically similar. Although the total land in the U.S. disturbed by mining is small, varying from 0.002 to 0.1 percent depending upon the reference, even the industry recognizes the great impact it has upon the land and the need for conservation and care of the environment. The transportation network in our country is responsible for far more landscape disturbance than all of mining. Agricultural land continues to account for 60 to 70 percent of total land use. Cropland, range, road cuts, and railroads are not viewed as disturbed areas despite their high visibility; people tend to see them as a necessary part of their everyday life.

\section{Exploitive}

Owen and Chiras (1995) began their examination of resource management with the age-old exploitation approach (man conquering nature) - viewing natural resources as inexhaustible commodities with nothing but individual profit in mind. The "get rich and get out" mining ethic had little concern for problems such as soil erosion, water and air pollution, or wildlife depletion. The purely exploitive approach to resource management did not consider problems created during the mining process or adverse effects that might occur in the future.

Mining does disturb land by removing surface vegetation and changing topography, and it may affect hydrologic function and water quality; hiking, the passage of off-road vehicles, and trailing by animals can produce similar effects (Toy and Hadley, 1987). Mining may also cause erosion and stream sedimentation, produce dust, lower water tables, or destroy wildlife and habitat. Additional vehicular traffic brings noise and increased wear on roads. With careful planning and responsible mineral extraction, most of these problems can be minimized or eliminated. Unfortunately, the damage created by exploitive aggregate producers and construction companies prior to the 1970's gave the industry a negative image, and the public has a long memory.

In today's world, the results of exploitive resource management usually require remedial action, often at taxpayer expense and with undesirable results. For example, in April 1997, the U.S. Forest Service and Army Corps of Engineers approved a restoration plan for Colorado's San Miguel River at the South Fork, which allegedly was damaged by Telluride Gravel mining operations. The river has been channelized and the water table lowered, with resultant death of trees along the banks. Telluride Gravel offered to provide labor and equipment for the restoration, but much damage had been done to the mining image. The public lost confidence in both the industry's and public service representatives' ability to do their job responsibly and stop further erosion (Editorials, 1997).

If they look objectively, even tourists seeking sun, sand, and surf in the Caribbean islands may find that their very presence has an environmental impact by increasing the need for local construction materials: but then, sand mined from beaches can result in serious coastal damage due to wave and wind action, as well as contamination of fresh water aquifers with salt water. Scientists at the University of Puerto Rico's Sea Grant Program and Millersville University are studying the effects of beach mining and coastal area management (Caribbean Coastal Studies, 1997).

Meanwhile, some islands have banned beach mining, resulting in higher costs, increased fuel consumption, and a search for alternative building supplies.

Back closer to Colorado, Riley County commissioners in Kansas considered a moratorium on sand dredging in the Kansas River. Dredges are used to mine via a floating platform and are a source of controversy. Tom Hittle, a landscape architect, told commissioners that prohibition is in the best interest of the community and State (Oakley, 1996). Sand and gravel deposits are found along stream valleys, and dredging "is widely used in large U.S. rivers and can increase sediment bed load through resuspension, physically eliminate benthic organisms, and destroy fish spawning and nursery areas, all of which ultimately change aquatic community composition" (Starnes and Gasper, 1995). In some reaches of the river, irresponsible dredging can lower the river bed, steepen and destabilize river banks, and cause increased erosion and channel widening. Kansas supporters of the moratorium claim that dredging harms birds that use the shallow sand bars for feeding and increases soil erosion along damaged river banks. Opponents of the moratorium argue that the bald eagle population is increasing, and thus deny significant environmental problems. The Kansas legislature adjourned after sending the moratorium bill back to committee and approved a 2-year study (by the State Department of Wildlife and Parks and the Kansas Water Office) of the river's potential for recreation (Associated Press, 1996).

In Colorado, 90 percent of wildlife habitat along streams and rivers has been destroyed (Leccese, 1996), largely by farming. Reclamation of sand and gravel pits to productive agricultural land, wetlands, or prairie is seen as a viable alternative to continued loss of soft space (dominated by the natural environment) or hardscape (expressed in architectonic forms and the built environment) development. 


\section{Preservation}

A preservationist approach to resource management sets land and natural resources aside, protected from future development or alteration. From a natural science point of view, systems do not stay the same forever and will change over time in spite of their official designation. For example, aspen (Populus tremuloides) is a pioneer tree invading sunny disturbed areas, eventually yielding to evergreen forest species. Tourists and mountain resorts want the aspen and their local ecosystem to remain unchanged indefinitely. Ironically, aspens colonize sites disturbed by fire, avalanche, landslide, logging, or mining. While one does not often think about preservation of mines, rural landscapes with significant historic mining sites are listed in the National Register and may contain shafts, tunnels, pits, and tailings - as well as surrounding communities. For example, the Central City-Black Hawk, Colo., area is considered a National Historic Landmark District, but most Coloradans and out-of-state visitors are more familiar with the towns' recently built casinos. Now, it is competition for parking that, indirectly, may take Black Hawk off the National Historic Landmark list: the National Park Service (NPS) has threatened (1999) to "de-list" the city for wanting to move a gingerbread Gothic structure named Lace House. Thus, landscapes evolve both biologically and culturally.

Wilderness regulation, another format to preserve landscapes by prohibiting resource development, considers human beings as visitors. The 1964 Wilderness Preservation Act legally defines wilderness as an area "where the earth and its community of life are untrammeled by man $* * *$." Thousands of visitors a year can have far greater impact on a landscape than a few hundred living on it. Throughout the Nation's national park system, the NPS is actively engaged in reclamation planning and at the same time involved in road surfacing and rehabilitation of public buildings. Many people may not realize that approximately 4,000 abandoned and 150 active mine sites exist within U.S. national parks. Even Yellowstone National Park has a history of mining activity, including sand and gravel pits to help maintain the 350 miles of road within the park.

The concept of pocket wilderness is being used for smaller, isolated areas; thus a small geographic area that has elements of significant landscape character, ecological systems, or fossil records may merit preservation. Features of historical as well as geologic value can impact a site. In Springwater, Ontario, an archeological survey, requested by the Ministry of Natural Resources, cost Cliff Varcoe Gravel Ltd. thousands of dollars (Lewis, 1995). The property, purchased for mining operations, turned out to be a significant historic native village and missionary site. The Canadian government ended up buying the land to preserve the 350-year-old village and protect the regional heritage and culture. In unique cases like this, mining usually is not an option.

On a local level, in Colorado, the Denver Regional Council of Governments approved a plan in 1997 to contain metropolitan development over the next 25 years. The plan includes regional open space, transit, and pollution control (Fong, 1997). Yet the "Metro Vision 2020" plan does not include a map delineating extractable materials within the 700 urban square miles. Such an oversight exemplifies the continuation of the patchwork quilt and mosaic of American landform, lacking the benefit of designing the larger spatial pattern to integrate and preserve natural features and potential resources. Many decisions are made on a small, local scale, envisioning only a short timeline. The macro view (including environmental data for off-site impact) over a long time frame that could help prevent landscape fragmentation continues to be avoided, probably for political reasons. By contrast, European governments frequently urge mining operators to look forward 60 years or more. Within the United States (where the average young family moves every 5 years), many people will continue to view their environment much as city governments do-in short time frames. With market demands for aggregate continuing to increase, both mineral extraction from irreplaceable resources and the subsequent resculpted landscape need to be examined both for areas that can be a high priority for mining operators and for areas that are to be preserved in their present condition.

\section{Utilitarian}

The utilitarian approach stems from developing natural "waste" land and making it productive. Germans have a name for dry wasteland of rocks and gravel_-Unland (Wiedenbein, 1994). The sensibility of what constitutes waste and productive land has changed over time. "Until the late 1960s, reclamation in the semiarid west invariably meant irrigation of dry lands to make them productive" (Hodder, 1977, p. 217). In other words, the "natural" land was unproductive and waste. Despite a semi-arid climate in Colorado (average annual precipitation is 17 inches per year), dry land can be a valuable ecological resource in itself. It should be noted that topography greatly affects moisture, as Colorado's higher elevations receive about three times more water than the plains. Early European explorers declared the Colorado area unfit for agriculture, but farmers proved them wrong with irrigation ditches. Some North American native peoples had cultivated the soil for centuries before. In recent times there has been a movement to preserve arid lands and return them to a natural state. It has been estimated that less than 20 percent of the country remains potentially natural (Stein, 1997). Within even that, wild indigenous vegetation is now exotic species. Many open spaces which we like to think of as pristine are degraded and naturalized by invaders such as Tamarix, Canada thistle (Cirsium scop. Kali), or leafy spurge. Even the tumble weed (Russian thistle, Salsola iberica) associated with towns of the Wild West is an introduced species.

Turning undeveloped, unused land (waste land) into something more productive is a major premise of housing development, but this development has a price. A green Kentucky blue grass lawn in Denver is no more "natural" than asphalt and requires frequent watering. With more than 15,000 herbaceous species in the family of Gramineae (grasses), relatively few are utilized in landscapes. Homeowners frequently are blissfully unaware of the damage they do in their own yards using fertilizer and pesticides. They do not want dust and noise from a quarry, but are attached to the noise and the resource expense of their lawn mower and edge trimmer. The National Gardening Association estimates that homeowners use up to 60 percent of the water supply in the West for lawn care. "And, according to the National 
Academy of Science, ten times more chemical pesticides are being used on lawns per acre than on farmland" (O'Neill, 1997).

In the United States, "xeriscape" has become a '90's catch word. Yet, the method is commonly not used because of the careful planning, higher initial expense, and expertise required to achieve a successful natural landscape in disturbed areaswhether it be new suburban developments or abandoned mines. Despite the lowered maintenance costs and water usage, xeric habitats are slow to be encouraged by developers, planners, and private parties. Considerable expertise is required to design a native plant community so that it looks natural. The composition and placement of native plants appear to be random when there is a complex underlying structure dependent upon soil and geologic structure. Hydrologic and climatic factors are important aspects of reclamation that are too often underevaluated. Precipitation and fluctuating temperatures impact slopes and accelerate soil weathering. Different vegetation may be required on south-facing slopes than north-facing. Xeric planning takes regional conditions into account and can be an important tool for reclamation efforts.

\section{Conservation}

Conservationists consider the ecosystem (including soil, wildlife, air, and water) as dynamic processes to be restored, protected, and enhanced. In an approach similar to sustainability, biological resources are managed to ensure quality and quantity before consumption (harvesting) occurs. For instance, streams can be stocked with fish, logged forests replanted. Aggregate, on the other hand, is considered a finite source that once removed from its original site cannot be recreated. Aggregate is nonrenewable (House, 1995). The construction industry continues to require fresh aggregate despite efforts to recycle materials and reduce waste. The industry must compete with other interests, often conservation interests, for resource-bearing land. Balancing ecosystem protection (conservation), agriculture, and an aggregate industry is a new challenge for all parties.

The Minnesota legislature funded a multi-disciplinary study on gravel mining and native prairie protection in 1995 . The study recognized the complex issue that "gravel deposits must be mined where they are found and cannot be relocated. Similarly, native prairie cannot be transplanted elsewhere" (Clay County Beach Ridges Forum, 1997, p. 2). Both are nonrenewable resources. Even the vice president of one of the area's largest gravel producers, Bob Stabo, stated, "We can't replace untouched, pristine native prairies" (Breining, 1996). Through scientific research, perhaps we can get closer to recreating them.

Earth science conservation is "concerned with safeguarding the rich heritage of rocks, minerals, fossils and landforms" (Mills and others, 1995). Mining sites can expose geologic features for study and produce diverse biological habitats, especially in areas of few natural outcrops. Along Interstate 70 (near Golden, Colo.), geologic outcrops were exposed in a claypit wall (fig. $3 A$ ) and from blasting for the highway construction (fig. $3 B$ ). The Interstate highway cut is a geologic landmark exposing layered sedimentary rocks that were deposited in horizontal sheets and bent up by the uplift of the mountains.

In England, a questionnaire was sent to mineral planning authorities and mineral operators to assess their attitudes to nature conservation as an appropriate after-use for mine reclamation (Mills and others, 1995). More than 80 percent were found to have policies on nature conservation in reclamation, usually combined with other after-uses: recreation, education, and landfill. Preferred areas for mineral extraction should be based upon balanced appraisal of the resources, landscape value, and land use by a group of mineral planners, environmental specialists, and landscape architects.

\section{Regulatory Considerations}

Federal legislation such as The Clean Water, Clean Air, Endangered Species, and National Historic Preservation Acts impacts mining, but does not automatically provide means to prevent pollution, erosion, or loss of wildlife and its habitat, nor does it guarantee a readily available supply of quality aggregate.

States may administer their own programs as long as their regulations are no less stringent than the Federal law. Permitting and regulation of 80 percent of sand and gravel mining is under the jurisdiction of State and local governments (Starnes and Gasper, 1995). Effective enforcement requires money and inspections, while downsizing of government may lead to fewer resources.

Aggregate mining in Colorado has been regulated historically under the "Colorado Open Mining Land Reclamation Act of 1973." The Act, with subsequent amendments, requires an approved mining permit and reclamation plan. Concerns regarding the extraction of construction materials were addressed in 1995 and defined "reclamation" as

the employment, during and after an operation, of procedures reasonably designed to minimize as much as practicable the disruption from an operation and provide for the establishment of plant cover, stabilization of soil, protection of water resources, or other measures appropriate to the subsequent beneficial use of such affected lands (Colo. Senate, 1995, p. 5).

Land-use regulations and zoning vary across Colorado from city to county. Mining laws for the Colorado Territory were enacted in 1861 after gold was discovered in the sand of the South Platte River near Cherry Creek (1858-59). Two-thirds of Colorado's population today lives in the South Platte Valley. Denver is situated in this broad, gentle river valley where landforms are visually more dominant than many in the Eastern United States. Gravel-capped terraces and Quaternary alluvium containing clay, sand, and gravel have been the source of local construction materials for many years.

It is the historical land abuse associated with coal and metallic mineral mining that has most influenced the current negative perception against all forms of mining. The first U.S. surface mining control legislation was limited in scope and enacted in 1939, by the State of West Virginia (Schaller and Sutton, 1978). Not until 1965 was the U.S. Department of the Interior directed to survey the environmental impact from strip and surface mining. Another 10 years passed before Congress established the Surface Mining Control and Reclamation Act. The realities of topographic variation, climate, economic factors, and scarcity of research information continue to influence the effectiveness of mine reclamation. 

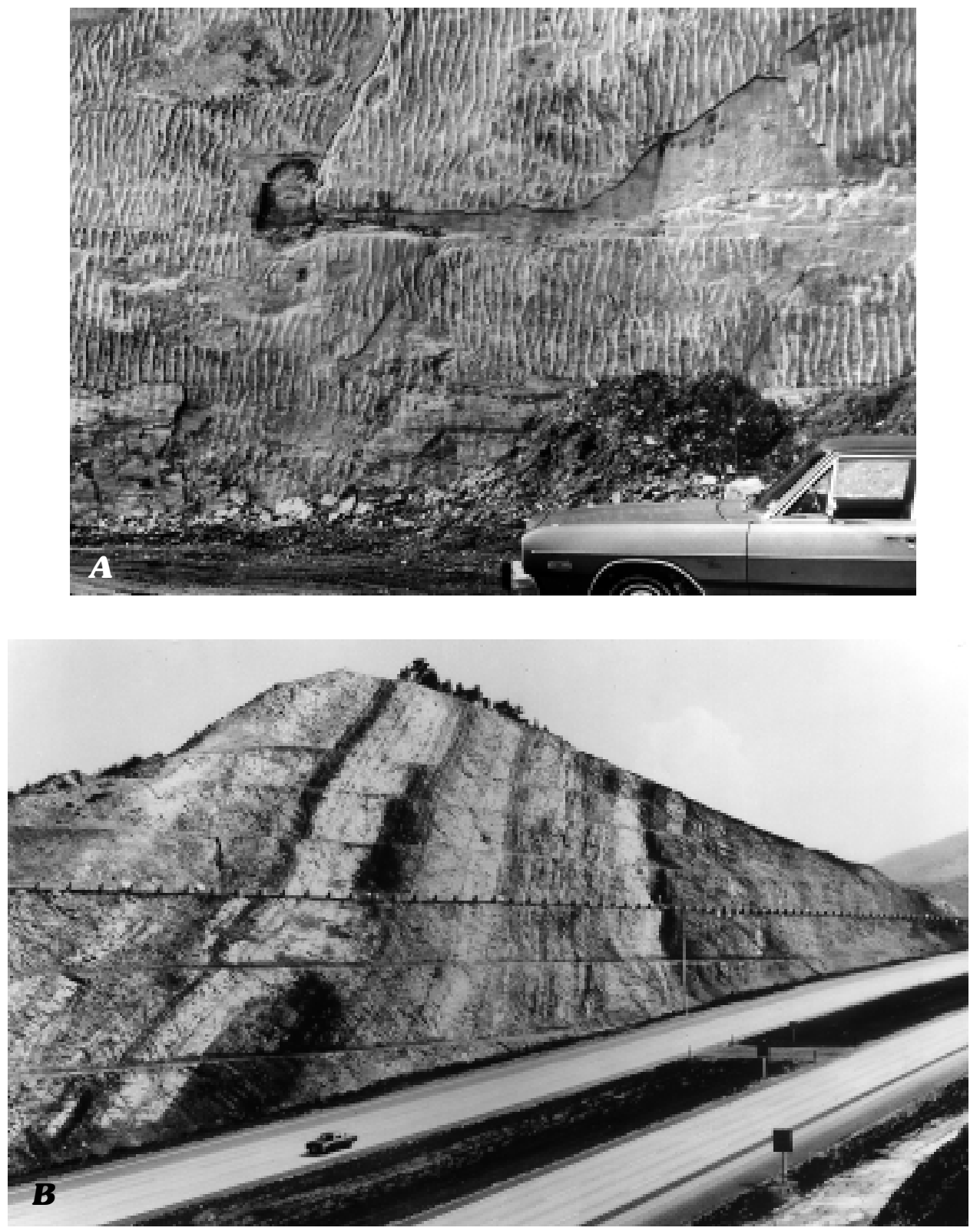

Figure 3. Rock features exposed by mining and road construction, Colorado Front Range. A, Oscillatory ripple marks in upturned beds of sandstone, 1982. Photograph by J.R. Balsley. Courtesy of USGS Photographic Library. $B$, Sequence of tilted strata at I-70 roadcut through the hogback, Jefferson County, Colo., 1972. Photograph by W.R. Hansen. Courtesy of USGS Photographic Library.

Within the U.S., land-use laws governing reclamation limit environmental impacts but are so broad that generally no review takes into account impacts of esthetic merit. Although the terminology may vary, the visual impact of a site needs to be considered, both positive and negative; it is one way to interpret the landscape and no less important than considering its resources or geology. Landscape character needs to be assessed, including integrating with elements beyond the site. There is usually no overall design scheme to integrate quarry perimeters into the greater landscape. Title 23 of the U.S. Code (governing the Federal Highway Administration) specifically considers "esthetic values" in balancing the "destruction of man-made and natural resources," costs, and the public interest. Yet, in Colorado and many other States, no landscape architect is required to review reclamation plans as part of the permit approval process.
Agencies involved in the approval process for Colorado mining permits include:

The State Historical Society

Colorado Division of Water Resources

Colorado Department of Health, Air Pollution Control Division

U.S. Bureau of Land Management or the U.S. Forest Service (if the proposed operation is on Federal lands)

U.S. Army Corps of Engineers

County Planning Department

Colorado ranks among the top five State producers in coal and has experienced problems with land subsidence and with fires in abandoned mines. It is the Appalachian coal fields that 
most publicized poor stewardship and "emasculation of physical resources" between the 1940's and 1970's (Simpson, 1985). That negative viewpoint of mining was reinforced when the Summitville, Colo., open-pit gold mine left acid-rock drainage requiring extensive remedial efforts. In 1992 the mine operator declared bankruptcy and abandoned the site. Cyanide solutions and soluble metal salts are just some of the environmental conditions requiring treatment at the gold mine. It is the horror stories (largely not related to aggregate mining) that make the headlines, not the successful, environmentally sound reclamation sites.

\section{Landscape Form and Change}

Human kind has labored at earth movement for millennia. Natural caves, pits, mud-bricks, and turf were fashioned for shelter long before the advent of drywall and plywood. Mountainsides were modified for people to make a living by forming agricultural terraces, roads, canals, and mines. Ramparts and trenches were devised to provide refuge, defense, burials, and monuments. Modern mining, however, continues to be subjected to scorn despite similar geometric patterns created by other industries and nature. Figures 4 and 5 illustrate that many of these disturbed landscapes have a common design form etched on and of the landscape.

Mining provides a natural resource to improve the quality of human life as well as an economic base for citizens of a region. Equally important is sensitivity to the geologic origin and natural pattern of the land. Without knowing the location and quality of resources, it is difficult to plan where future growth should occur.

Human impacts on any area that humans disturb - for this discussion, by mining, in particular-include long-term changes to landform (movement/massing of earth), water table, and texture (soil disturbance and exposed rock surfaces). Nature changes a landscape through long-term processes such as weathering (wind and water erosion) and short-term events, such as volcanic eruptions, earthquakes, and flooding. Individuals can also change land very quickly, with subsequent long-term effects. With a national trend toward increased use of hard rock, it is useful to examine the surface topography of hard rock and sand and gravel mines.

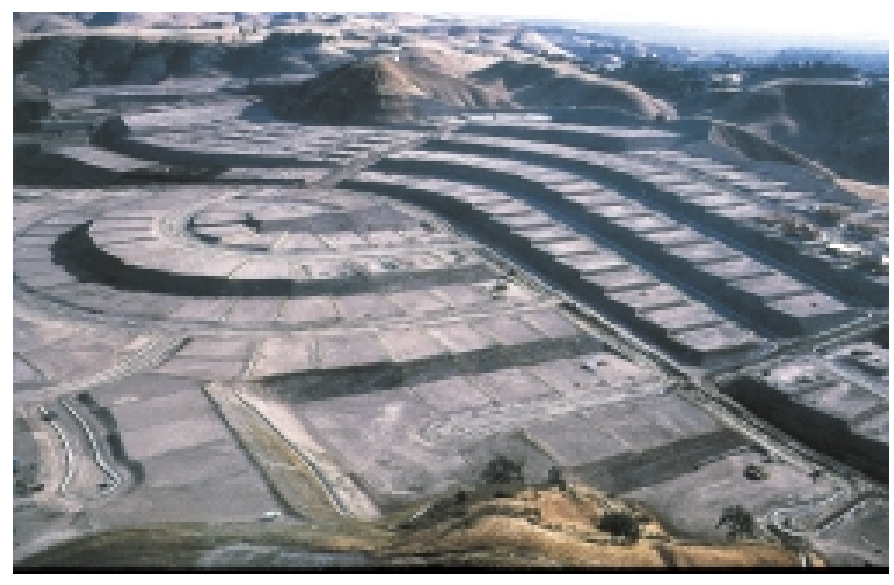

Figure 4. "Earthworks for Hillside Housing." Near Los Angeles, Calif. Photograph by Alex S. MacLean (Corner and MacLean, 1996, p. 67). Courtesy of Yale University Press, New Haven, Conn.
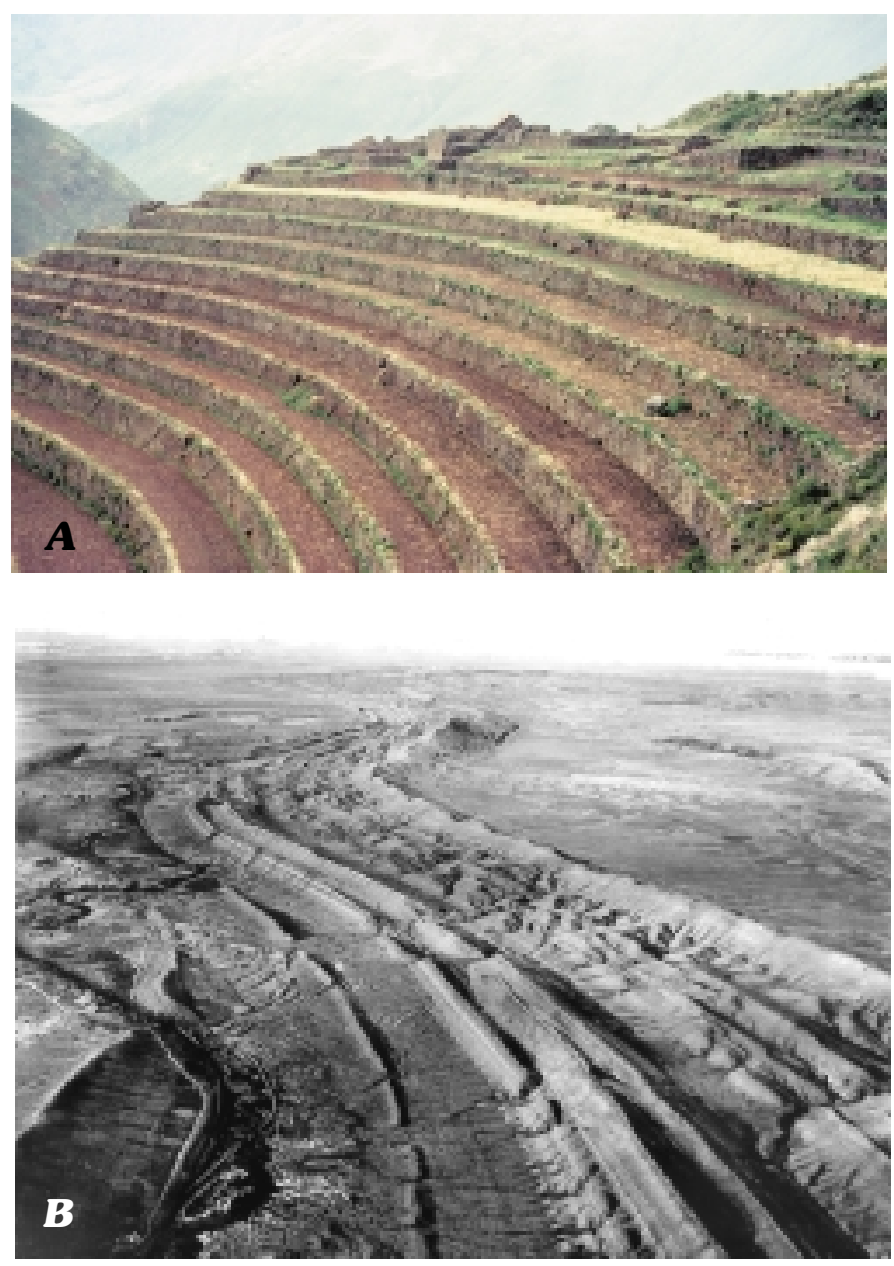

Figure 5. Geometric landforms produced by humans and by geologic processes. A, Agricultural terraces in China. Courtesy of the Denver Natural History Museum. B, Tilted beds between Rawlins and Laramie, Wyo. Note the highway and the form of the "stepped benches" on a megascale. Photograph by J.R. Balsley. Courtesy of the USGS Photographic Library.

\section{Surface Topography}

Because highwalls in quarries create potential safety issues, some States have limited all surface reclamation grades to not exceed a $35^{\circ}$ slope, generally the angle of repose for spoil material. Stone quarries have physical characteristics that may require blasting or backfilling to comply with such regulations, thus increasing reclamation costs. Fill material is subject to settling, and the site needs to meet engineering standards for post-mining use such as landfills (hazards posed by disposing of solid waste), water storage reservoirs (soil type for high imperviousness), or development (soil compaction and determination of bedrock depth). Along the Front Range of Colorado, reclamation of sand and gravel pits typically involves reducing side slopes, spreading topsoil, and establishing vegetation on the side walls, with a shallow lake covering the pit floor. Colorado law (Colorado Senate, 1995) requires slopes no steeper than a ratio of 2:1 (horizontal to vertical ratio), except from $5 \mathrm{ft}$ above to $10 \mathrm{ft}$ below the expected water line, where slopes cannot be steeper than $3: 1$, when a lake or pond is produced as part of a reclamation plan. If swimming is to be permitted, the slope cannot be steeper than 5:1 in the swimming area. Safety 
benches are not specified. Wildlife also prefers gentler slopes, yet high banks are the norm in reclamation. Nothing is mentioned in the regulations of the importance of nonlinear shorelines (coves), shallow waters, and islands for habitat value. Designing for shallow waters can be the starting point for wetland design.

\section{Dry and Wetlands}

Reclamation of a mining area is commonly influenced by elevation above or below the water table-whether the bottom of the mined area is wet or dry. With surface mining viewed as an interim use, planners and operators need to think of the long-term objective when impacting the water table.
Broad historical precedent exists for any number of successful after-uses: conservation, recreation, public facilities, commercial/industrial, residential, recycling, and storage. Agriculture is most needed in rural areas, while recreation is useful for urban centers. The shallower slope of sand and gravel pits, requiring less earth moving and grading than quarries, makes them better suited for reclamation to residential, commercial, and agricultural uses. Sand and gravel mines are discouraged for use as landfills but offer great potential for stormwater retarding basins (storage technique to reduce downstream flooding). Wet bottoms are more suitable for bird habitat or development for water recreation. Table 2 summarizes various after-uses identified in the literature, organized by their relation to the water table.

Table 2. Types of after-use for mines located below (wet bottoms) or above (dry bottoms) the water table. [\#=sand and gravel pit; ${ }^{*}=$ hard rock quarry]

\begin{tabular}{|c|c|c|}
\hline Land use & Wet site & Dry site \\
\hline Conservation: & $\begin{array}{l}\text { Fish spawning \# } \\
\text { Passive lakes } \\
\quad \text { Aquatic habitat * \# } \\
\quad \text { Waterfowl habitat * \# } \\
\text { Riparian habitat \# } \\
\text { Wetland habitat * \# } \\
\text { Beach restoration \# } \\
\text { Stream restoration \# } \\
\text { Threatened/endangered species \# }\end{array}$ & $\begin{array}{l}\text { Native plant revegetation * \# } \\
\text { Wildlife habitat * \# } \\
\text { Historical * } \\
\text { Nature center * \# } \\
\text { Threatened/endangered species * \# }\end{array}$ \\
\hline Recreation: & $\begin{array}{l}\text { Active lakes } \\
\text { Waterslide resort \# } \\
\text { Swimming * \# } \\
\text { Water-skiing \# } \\
\text { Fishing * \# } \\
\text { Boating and sailing \# }\end{array}$ & $\begin{array}{l}\text { Botanical garden *\# } \\
\text { Golf course *\# } \\
\text { Casino \# } \\
\text { Hiking, bicycle and horse trails \# } \\
\text { Motorcycle track \# } \\
\text { Theme amusement park \# } \\
\text { Public parks \# * } \\
\text { Hunting, camping \# } \\
\text { Soccer, football, and baseball fields \# }\end{array}$ \\
\hline Public facilities: & $\begin{array}{l}\text { Harbor } * \\
\text { Tidal pool * } \\
\text { Sculptural \# }\end{array}$ & $\begin{array}{l}\text { College campus \# } \\
\text { Hospital \# } \\
\text { Restaurant \# } \\
\text { Amphitheater * \# } \\
\text { City hall * } \\
\text { Sculptural * \# } \\
\text { Permanent easement for utilities and highways * \# }\end{array}$ \\
\hline $\begin{array}{l}\text { Commercial/ } \\
\text { Industrial: }\end{array}$ & $\begin{array}{l}\text { Academic research * \# } \\
\text { Ferry terminal } *\end{array}$ & $\begin{array}{l}\text { Academic research * \# } \\
\text { Light manufacturing \# } \\
\text { Office \# } \\
\text { Shopping center * \# }\end{array}$ \\
\hline Residential: & $\begin{array}{l}\text { Sewage treatment \# } \\
\text { Water quality improvement \# }\end{array}$ & Housing * \# \\
\hline Recycling: & $\begin{array}{l}\text { Ground water recharge \# } \\
\text { Wastewater treatment * }\end{array}$ & $\begin{array}{l}\text { Pasture *\# } \\
\text { Cropland *\# } \\
\text { Forestry *\# } \\
\text { Composting \# } \\
\text { Methane production * }\end{array}$ \\
\hline Storage: & $\begin{array}{l}\text { Water supply *\# } \\
\text { Flood control \# } \\
\text { Inert fill material \# }\end{array}$ & $\begin{array}{l}\text { Livestock shelter * } \\
\text { Equipment } * \\
\text { Food } * \\
\text { Trains (city transit) \# } \\
\text { Cemetery * } \\
\text { Sanitary landfill * \# }\end{array}$ \\
\hline
\end{tabular}


Although constructed wetlands are not the same resource as natural wetlands, they are capable of providing wildlife and recreational benefits while moderating and improving the quantity and quality of water. Wetlands are the subject of frequent argument and have sometimes been considered waste areas to be filled or drained to make "productive" lands. Once justifiably associated with mosquitoes and disease, wetlands are still affected by misconceptions about their value. The rate of wetland destruction has slowed, but "over a period of 200 years, the lower 48 states have lost an estimated 53 percent of their original wetlands" (Dahl, 1990, p. 1). A high percentage of wetland losses is attributed to agricultural land conversions. The term wetland is broadly used to describe areas that are transitional between terrestrial and aquatic systems. Wetlands include swamps, bogs, marshes, fens, and even certain bottomland forests, meadows, and floodplains. These areas play an important role in the environment by supporting specific aquatic, soil, and vegetative life. Geologically, wetlands are dependent upon disturbance or cyclic fluctuations in hydrology and will fill in without seasonal flooding. Mining reclamation can take a lead in both the research and demonstration of wetland production. The Des Plaines River Wetlands Demonstration Project in Lake County (north of Chicago, Ill.) utilized three abandoned quarry lakes in reconstructing wetlands for wastewater treatment (Smardon, 1989). Littoral zones (the area between shoreline and a depth of about $20 \mathrm{ft}$ ), a sediment trap for suspended solids, and backwater areas were constructed through the quarries. The experimental project will aggrade the river system and provide information on economic, ecological, esthetic, and recreational benefits. Smardon pointed out that a key question is whether user and public groups are able to perceive the benefits and whether this translates into public acceptance (p. 293).

Water tables become an issue if the site is excavated into shallow aquifers. In alluvial valleys, where ground water could seep into sand and gravel pits, it is sometimes cheaper to let the site simply become a water storage facility by lining the pit with clay. That is changing with stricter water rights. Colorado requires the operator to make up the volume of exposed ground water lost to evaporation. Sites for future water storage may involve the purchase of water rights first, so no longer is this a cheap method of mine reclamation. Pit sites above the water table can be returned to certain pre-mining conditions more successfully (such as agriculture) than pits below the water table.

\section{Natural and Cultural Patterns}

An important aspect of mine site mitigation and reclamation can be the recognition of basic natural forms and then creatively applying those patterns to design opportunities with nature. Bare and severe landscapes are considered unattractive unless a strong bold pattern can be detected. Antelope Canyon in southern Utah,

Table 3. Natural patterns of hard rock (quarry) and sand and gravel (pit) mines in the U.S.

\begin{tabular}{|c|c|c|}
\hline Natural form & Quarry & Pit \\
\hline Space & Large-scale, deep & Medium-scale, shallow \\
\hline Mass & Vertical & Curvilinear \\
\hline Color & Light and dark & Gray \\
\hline Texture & Angular, coarse & Rounded, smooth \\
\hline \multicolumn{3}{|l|}{ Enclosure: } \\
\hline Perspective view & Perpendicular & Planar \\
\hline Visual zone & Shortened & Extended flowing lines \\
\hline Configuration & Areal—Single large area & Linear-Narrow strip \\
\hline $\begin{array}{l}\text { Geology: } \\
\text { Origin }\end{array}$ & $\begin{array}{l}\text { Magmatic, metamorphic, } \\
\text { sedimentary }\end{array}$ & $\begin{array}{l}\text { Stream valley and terrace, } \\
\text { glacial deposit, } \\
\text { marine terrace }\end{array}$ \\
\hline Slope & Steep & Gentle \\
\hline Soil & $\begin{array}{l}\text { Unstable } \\
\text { Faster weathering }\end{array}$ & $\begin{array}{l}\text { Rather stable } \\
\text { Slower weathering }\end{array}$ \\
\hline Water & $\begin{array}{l}\text { Retentive floor surface } \\
\text { Less infiltration on slopes }\end{array}$ & $\begin{array}{l}\text { Permeable floor surface } \\
\text { Greater infiltration rate }\end{array}$ \\
\hline Scarcity & More plentiful in East & More plentiful in West \\
\hline Wildlife habitat & Moderately complex & Simpler \\
\hline \multicolumn{3}{|l|}{ Cultural: } \\
\hline Metaphor & Mountain, creation & Water, entropy \\
\hline Mining impact & $\begin{array}{l}\text { Blasting, highwalls } \\
\text { Smaller quantity of waste }\end{array}$ & $\begin{array}{l}\text { Settling ponds, dust } \\
\text { Sometimes significant waste }\end{array}$ \\
\hline Longevity & Long-term & Short-term \\
\hline
\end{tabular}



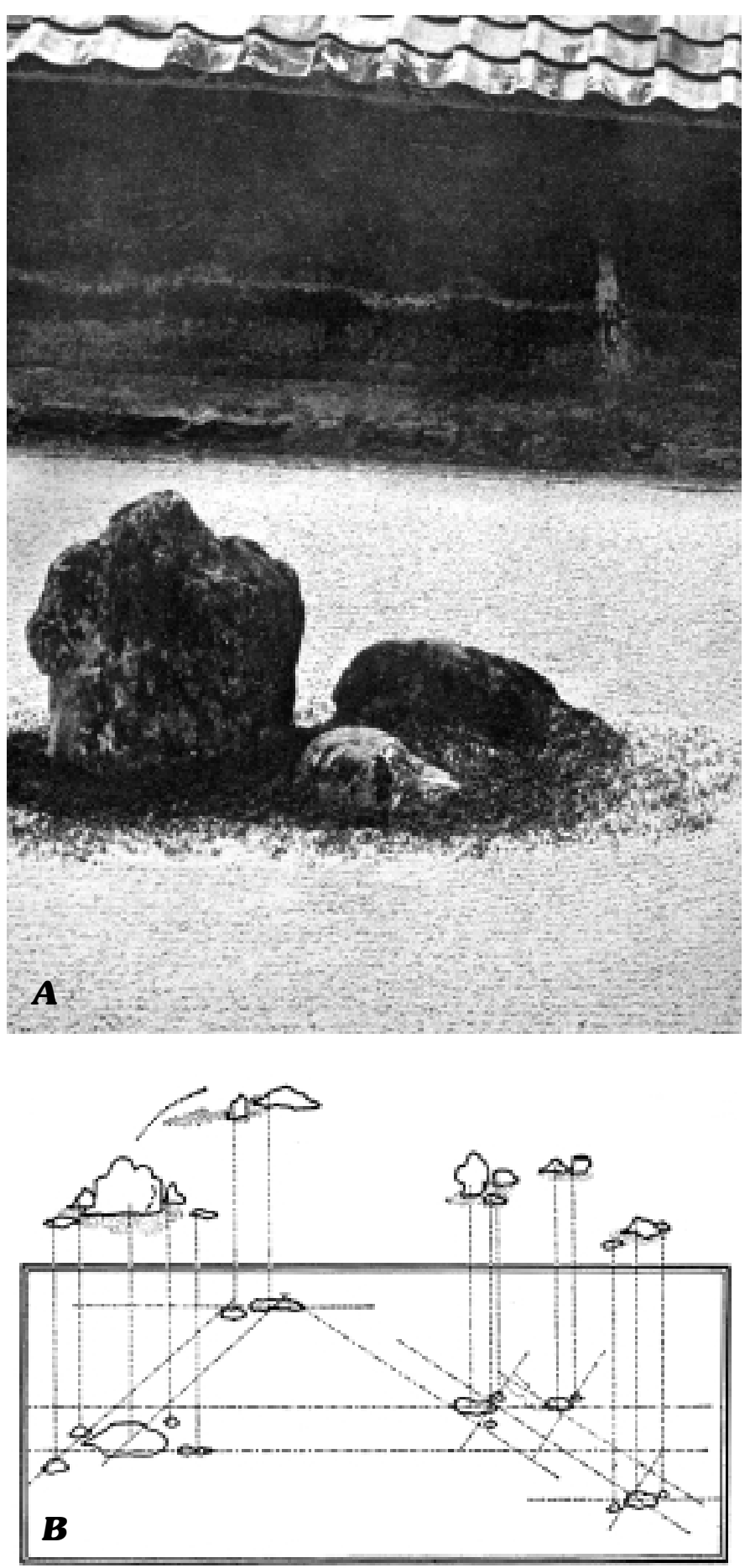

Figure 6. Ryoan-ji, circa 1488-99; within the Daiju-in monastery, Kyoto, Japan. From Jellicoe and Jellicoe, 1987, p. 96. A, Zen garden of contemplation. Photograph by Susan Jellicoe. B, Diagram showing plan view. Drawing by Geoffrey Jellicoe.

for example, is seen as a natural architectural wonder, and in some aspects it is not unlike an abandoned hard rock quarry. The landscape character of irregular topography, steep vertical stone walls, the possibility of water, and a variety of microclimates present advantages to designers. The disadvantage is that modern equipment can excavate areas on a scale that dwarfs the individual experience and if unreclaimed, such areas can remain noticeable and desolate for years in arid climates. Low temperature, wind, and short growing season are other climatic factors that can hinder reclamation efforts and slow land recovery, especially in alpine and arctic environments.

A number of terms are needed to illustrate some general attributes of hard rock quarries and sand and gravel pits. "Landform" refers to the image from a broader perspective. "Enclosure" is defined by the proximity and form of the overhead, base, and wall planes (in the case of mining, by the subtraction of mass). In both cases, quarry and pit, the space is not fully enclosed. Rather it is implied by the wall edge and level changes, termed "inscribed space." The "visual zone" is that area which can be seen from the mine floor, whereas the "perspective view" is from outside that zone.

"Configuration" is the basic spatial distribution of mines within the regional landscape. Consolidated rock quarries usually comprise large areas of the resource and operate for a longer duration (generally upwards from 30 years, some for more than 100 years); waste production is small. Sand and gravel operations tend to a larger number of pits occupying smaller narrow winding strips, due to the relatively small volume of available material, with a shorter life span (often 15 to 30 years); waste can be significant at times. These are broad categories and not meant to be comprehensive. Table 3 lists the attributes for quarry and pit mining.

The emotional response to a landform is related to the use of metaphors. In Japan, since Zen Buddhism arose in the late 12th century, stone has been used to create abstract nature, a microcosm, or a view of the universe. For an Eastern esthete, sand and gravel are natural elements to be designed, groomed, and raked into a contemplative dry landscape, kare-sansui. An ideal for the mind, water is suggested with coarse sand, and mountains (landforms) are symbolized by rocks. Empty space itself becomes as important as the surroundings. Ryoan-ji, Kyoto, Japan, is the most famous example (fig. 6). Raked river-bed quartz is bounded by a temple verandah; 15 rocks are set out in five groups. The western eye can develop an appreciation for these minimal designs and recognize that not all of nature is valued in green pastoral scenes. A sand and gravel pit offers more to be viewed and understood than simply as "derelict" landscape. An exhibit titled "I Am Sorry" at the Watari Um Museum (1995) in Tokyo, Japan, could be interpreted by the author as representing the failure (or celebration) of construction materials as art (fig. 7). The sandpainting contains cement balls on a sand and gravel plane ( $23 \mathrm{ft}$ by $23 \mathrm{ft}$ ) and, according to the website in which it appears, is concerned with apologies for the 1945 bombing of Hiroshima and Nagasaki. Imagine the same design laid out on a 2-acre site.

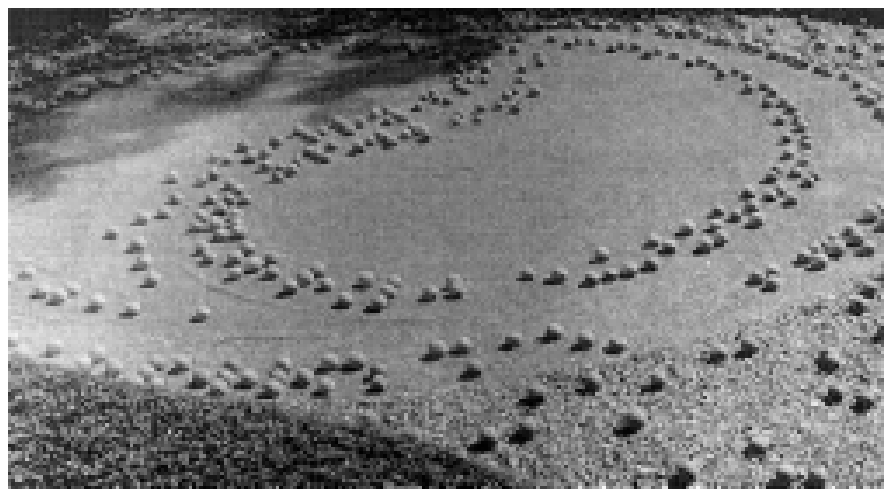

Figure 7. "I Am Sorry," 1995. Sand, gravel, and 1,000 cement balls. Watari Um Museum, Tokyo, Japan. 


\section{Esthetics and Ecology}

Many land-use decisions are not based upon visual attributes and esthetics because these factors are viewed as "nonscientific." No matter how scientifically sound a mining operation may be, it is the visual impact that can generate immediate and vocal opposition. Mills and others reported that there is a visual preference for the more diverse landscape (1995), yet confusion arises in what we expect nature to look like. The National Environmental Policy Act defines esthetics as "the science or philosophy concerned with the quality of visual experience." We make esthetic decisions every day. The dress or tie one wears to work, the meal one chooses at a restaurant, are all subject to biological sensory resources including sight, smell, taste, sound, touch, and movement; all part of a physiological function. Webster's Ninth New Collegiate Dictionary (1991) defines "aesthete" as a noun: one having or affecting sensitivity to the beautiful, especially in art. Everyone has an esthetic sense with definable attributes and perceptions of nature/landscape rooted in culture, past experience, and evolution. It is the emotional response to a given landform that is highly personal. One hypothesis called habitat theory seeks to relate pleasurable sensations in the experience of landscape to environmental conditions favorable to survival. Esthetics become simple pleasurable or anxious responses to the landscape and its ability to satisfy our biological needs.

It is in the visual perspective and understanding of landscape that individual heritage and life experience impacts us. Recognizing a meaningful place connects us to the environment; landscape architects merge art with science in creating landforms with a social function, designing elements for a specific experience. One landscape can tell different stories to many people. Unconsciously, we compare new spaces with old, visually choosing familiar sights over unfamiliar. Local values impact perceptions so that a Dakotan may find the blank canvas of an open field more attractive than the dense understory woodland preferred by a Virginian. A farmer looks at fields of linear geometric patterns as signifying agricultural bounty, while an environmentalist may see soil erosion and pesticides (fig. 8). The farmer views water as a necessary commodity for his crops, the hydrologist a precious resource to be saved, the geologist a factor in surface erosion, and the meteorologist an atmospheric measurement to help with weather predictions. All are valid points of view.

Culture is our beliefs, customs, economics, and social patterns, while nature is the flora and fauna in a community (including climate and geology). The Western civilization perception of landscape is predicated upon a visual bias favoring a "clean, tidy, and safe" environment, and since the 18th century, the "picturesque." Death and decomposition are part of nature - realities considered messy and experiences to be ignored or at least prettied up by our society. A site may be designed well ecologically, but without public understanding of its function or positive visual reinforcement, it could end up condemned. A scientific experiment may involve contouring a mined-out pit to fit the surrounding topography, leaving nature to take its course. If the community perceives the site as messy and complains, the project has failed in the sense that viewers are responding with a preferential judgment rather than evaluating the landscape from a natural process. As a different example, indigenous buffalo grass (Buchloe dactyloides) is looked upon by some people as a sign of an unkempt lawn because it is slow to green up in the spring, a natural dormancy character for adaptation to extreme weather conditions. Its value is low to people without an understanding of its biological function.

Webster's shows "landscape" as a verb meaning "to modify or ornament $* * *$ by altering plant cover" and as a noun, where visual connotations come to mind of scenic vistas and regional landforms. In the past, human beings viewed the landscape as wild and fearful-something to be tamed and controlled. If scientists and designers became familiar with the term "landscape" more fully, they might see their work as beneficial. The interaction of people and place is a powerful process. Land planners,

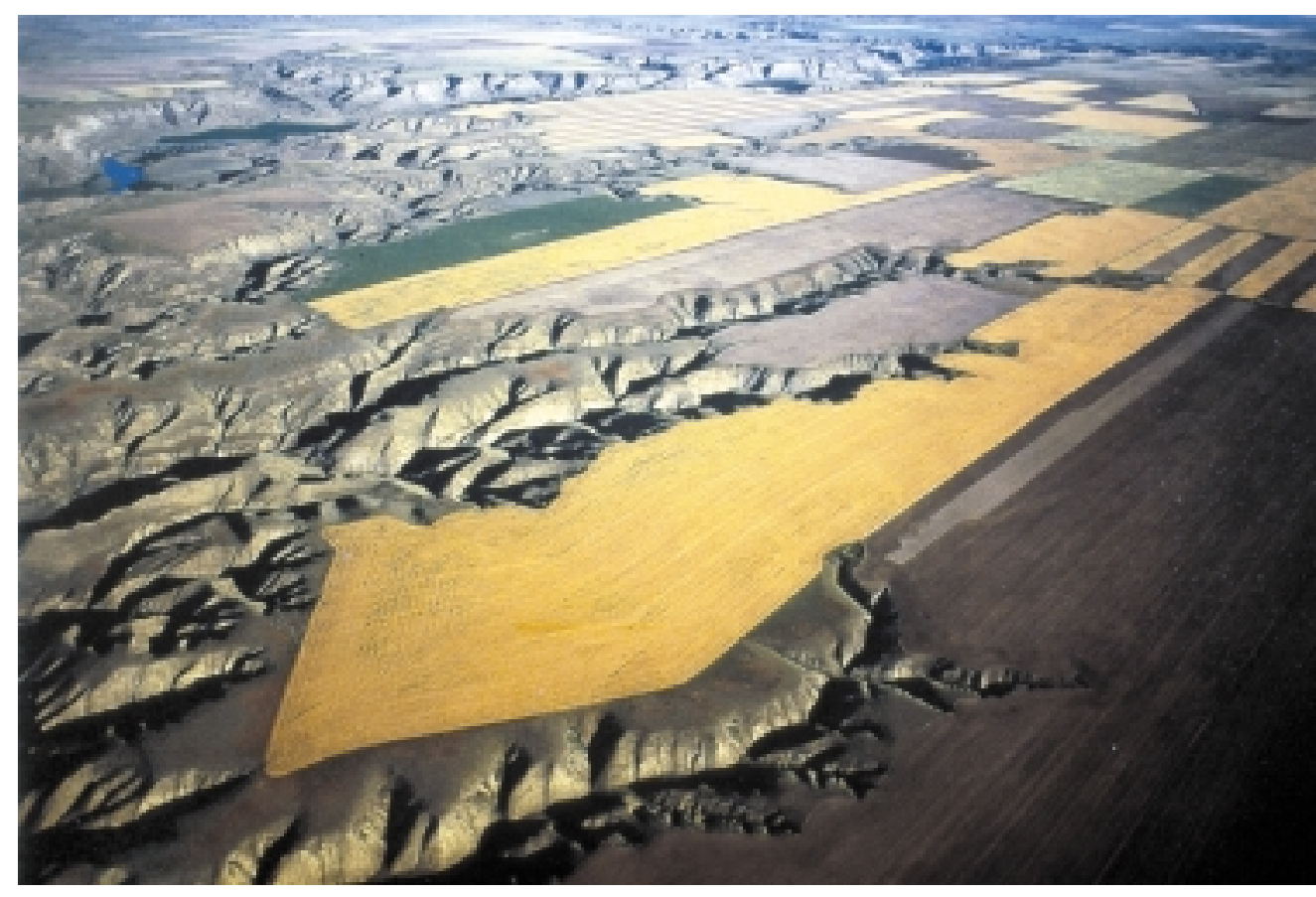

Figure 8. "Wheat Fields on Tablelands Cut by the Marias River," Cutbank, Mont. Photograph by Alex S. MacLean (Corner and MacLean, 1996, p. 129). Courtesy of Yale University Press, New Haven, Conn. 
developers, and scientists are becoming more aware of the need to communicate in a common language. The word "design" is also both a verb and a noun. Wisely shaping our environment requires that we prepare a plan with a scientific process (verb) and produce a product (noun). Design work for reclamation needs to respond to a site's physiography, ecology, function, artistic form, and public perception.

\section{Design Approaches}

A study of landfill and sewage treatment by Engler (1995) discussed eight different approaches to designing waste landscapes. Mining generates a disturbed landscape that many consider waste until it is reclaimed by nature or by human efforts. Engler's language appears adaptable to reclaimed mine sites with minor reinterpretation of her terminology (table 4).

\section{Natural}

Wait long enough and no matter the disturbance, nature works to regenerate with or without help from human beings; thus the adage "time heals all wounds." A conscious natural design approach may be one of hands off. Some areas devastated by fire, landslide, volcanic eruption, or quarrying manage to recover without human intervention. Areas that have been strip mined and where topsoil has been removed are difficult places for many life forms to reestablish. The same is true where loss of habitat by other means endangers one or more species and on lands where human activities or natural processes have resulted in a buildup of toxic materials. Given enough geologic time, a small site scale, and stable (nondisturbed) adjacent ecosystems, disturbed areas recover without human input. Alaska's moist climate, dense vegetation, and remoteness are suited for some abandoned pits to be passively reclaimed by nature. Heavy equipment brought in to recontour these old sites may do far more damage to the existing ground cover and surface soil than the benefit gained. Long-term natural recovery, however, may or may not bring about the specific changes people find desirable. For example, how many people living near Appalachian mining sites want to wait 30 years for hardwood seedlings to sprout? Disused quarries also offer an opportunity for "pioneer" or early successional plant species to establish. In Scotland, the rare plant Lychnis viscaria usually occurs only on rocks and cliffs, but the plant is abundant in one disused quarry (Usher, 1978). Studying nature's ability to heal is one way scientists and designers can learn new techniques for reclamation, taking maximum advantage of natural geologic and biological processes.

In Colorado, little remains of undisturbed prairie due to grazing and farming. Reestablishing short-grass prairie would provide a native vegetative cover that is self-sustaining, and requires little maintenance, fertilizer, or water. Of even greater benefit is the establishment of wildlife habitat and the possibility of providing physical linkages between different areas of habitat. The initial cost to establish a prairie grass may be higher than for conventional seed mixtures, but the long-term benefits are considerable. Adjacent to the Poudre River, Colo., a sand and gravel pit was used to test natural seedfall for restoration of cottonwood (Populus spp.) and willow (Salix spp.). The WREN pit project (fig. 9), a cooperative study, was conducted by Western Mobile Corporation, Colorado State University, and the U.S. Geological Survey. Controlled flooding was used to "simulate historic spring flooding conditions along the Poudre River" to establish vegetation (Gladwin and Roelle, 1997). Undesirable exotic saltcedar (Tamarix chinensis) seedlings were exterminated by timed floodings. With short seed viability for some seeds (for example, less than 2 weeks

Table 4. Design approaches to reclaiming mine sites.

\begin{tabular}{|c|c|c|}
\hline Authors' list & Engler's list ${ }^{1}$ & Description \\
\hline Natural & - & $\begin{array}{l}\text { Allow nature to reclaim site with no or } \\
\text { minimal human influence. }\end{array}$ \\
\hline Camouflage & Camouflage & $\begin{array}{l}\text { Conceal mining facility using visual } \\
\text { screens and buffers. }\end{array}$ \\
\hline Restoration & Restoration & $\begin{array}{l}\text { Return the land to its approximate } \\
\text { original contour. }\end{array}$ \\
\hline Rehabilitation & Recyling & Use site for public amenities. \\
\hline Mitigation & Mitigation & $\begin{array}{l}\text { Repair a mined-out site from extensive } \\
\text { human or natural damage. }\end{array}$ \\
\hline Renewable resource & Sustainable & $\begin{array}{l}\text { Recycle man-made or natural } \\
\text { resources on site. }\end{array}$ \\
\hline Education & Educative & $\begin{array}{l}\text { Communicate mining or other re- } \\
\text { source information through outreach. }\end{array}$ \\
\hline Art & Celebrative & $\begin{array}{l}\text { Treat site as work of beauty and } \\
\text { unique experience. }\end{array}$ \\
\hline Integration & Integrative & $\begin{array}{l}\text { Combination of approaches integrat- } \\
\text { ing art and science. }\end{array}$ \\
\hline
\end{tabular}

${ }^{1}$ One approach Engler did not mention is the oldest one around-nature itself. As this concept is used more and more by public agencies, it is recognized that going into an area in the attempt to repair it, people may sometimes do more damage than previously existed. Although a combination of the design approaches is most often applied, it is still useful to examine the specific categories with examples. 
for willows) flood timing is critical (Manci, 1989). In arid regions, irrigation may be necessary for the first 150 days to ensure that cottonwood roots gain access to the water table. The WREN pit is an example of semi-native riparian vegetation being used to reclaim a site with little human involvement and cost.

When health and safety become a factor, a natural approach may not be appropriate, and some form of treatment may be required. Abandoned quarries can become dangerous water holes, unsanitary waste sites, or subject to landslides. Derelict sites often make news, such as closed granite quarries in Quincy, Mass., that have been used for youthful rites of passage: since 1963, twelve boys have been killed jumping into the deep pools of water (Sullivan, 1996). Such quarries may have impermeable floors that must be fractured for the rock to allow water drainage, or require regrading of steep slopes.

\section{Camouflage}

Camouflage uses visual screens and buffer zones to conceal the mining facility. It is a cosmetic surface treatment of problems that have complex solutions. Typically, an immediate response by the industry is to utilize fences, earth berms, and plantings (small-scale features) to visually isolate the activity

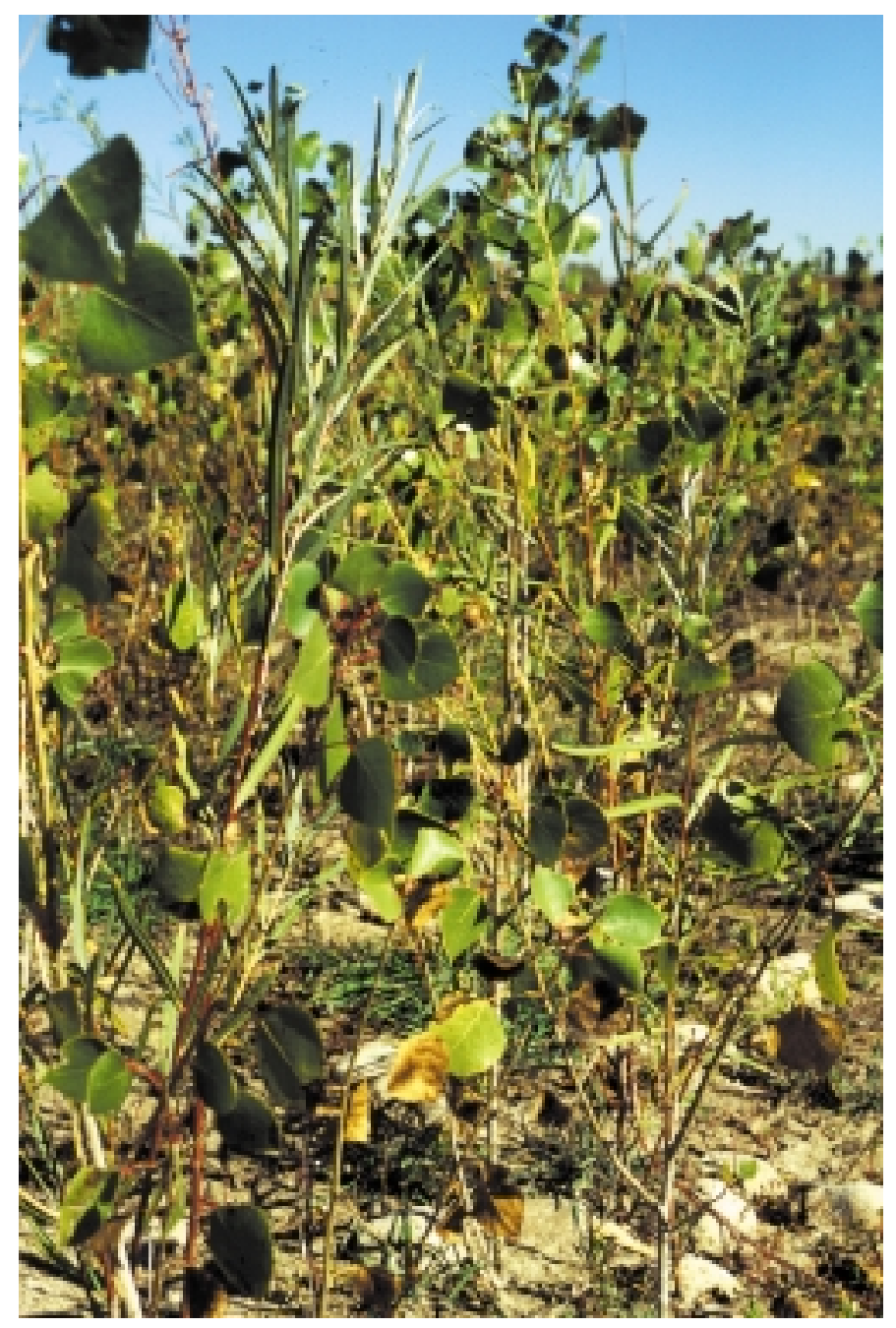

Figure 9. Cottonwood and willow restoration in a mined-out sand and gravel pit, Fort Collins, Colo. Photograph by B. Arbogast.

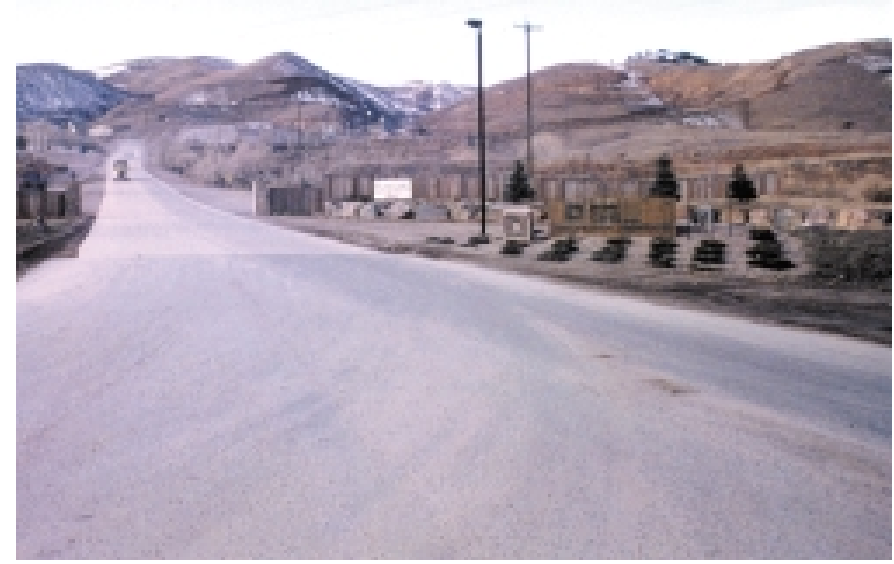

Figure 10. Vehicular entrance to a mining facility. Photograph courtesy of Western Mobile, Boulder, Colo.

from residential areas. Sand and gravel pits are harder to camouflage than hard rock quarries because the ground plane is silhouetted against the sky. As an interim approach, the visual relationship between the project site and physical setting (largescale features) and environmental patterns needs to be considered. The National Environmental Policy Act calls this relationship the "visual equivalent of good manners and can be very important to community acceptance of a project" (American Society of Landscape Architects, no date). Ideally, a natural buffer zone would remain undisturbed throughout the active mining phase, but economics usually force mining as close as possible to the edge of the permitted area. Setbacks from streams are even more important environmentally and should be at least $200 \mathrm{ft}$ wide (Norman and Lingley, 1992).

The camouflage approach is frequently associated just with the site perimeter (fig. 10). Wide buffer zones are frequently abandoned in the interest of cost. Linear, uniform rows of quickgrowing plant species are commonly used for windbreaks and camouflage, and do not necessarily reflect a long-term planning scheme. A longer term approach could include using quickgrowing species as part of a matrix containing slower growing native species matched to grow in overburden or spoil material. Another consideration should be the profound effect vegetation cover has on water and soil (increased infiltration capacity and decreased erosion).

Neither mine operators nor neighbors want noise and dust from an active mine. Nor does the State environmental protection division or U.S. Environmental Protection Agency (EPA) want problems with dirty air and water. Exposed mine surface area is kept to a minimum, while in most places dust suppression is accomplished with pressurized water and a surfactant. Dry dust emissions are also controlled by filters on equipment. Onsite equipment, with accompanying vibrations and noise, also creates an impact and frequently needs to be screened. Engler pointed out that by masking sites, "we continue to inhibit public perceptions and restrain public care for waste problems" (1995, p. 17). The reality is people want the product but do not want the inconvenience of its production. An educational opportunity is lost by pretending that mining does not have an impact on the 
landscape. As a comparison, while some cities have made historical walking tours out of the miles of underground water and sewage pipes, Western society prefers such infrastructure systems remain out of sight, hearing, and smell. We all produce waste water but do not want to see beyond the toilet bowl.

Peter Austin (1995, p. 27) called using landscape skills "merely to provide a cosmetic touch to an otherwise ravaged landscape, an exercise akin to putting lipstick on a pig." This may have been more nearly true in the past when reclamation took a backseat to exploration; as we have suggested, there are still instances where a minimal approach is justified.

\section{Restoration}

Returning the land exactly to its original condition is a restorative approach. Mining is then considered a temporary activity that leaves a disturbed area requiring a return to its pre-mining biological conditions. Restoration as so defined is seldom possible because we do not currently have the information and skill required to return ecosystems exactly to their original structure. Germany has made attempts in coal mining, recording the location of every tree and rock in a pre-mining survey. Furthermore, complete biological restoration is seldom possible because many native organisms do not return to the same ecological niche. Instead the new land will be environmentally unstable, and exotic species are ready to invade disturbed sites. Some U.S. States do not even require companies to remove and replace the topsoil. A more realistic approach than exactly original condition is to restore the new habitat as close as possible to its original function and recapture the landscape character.

Planned, sequential mining of aggregate deposits accompanied by concurrent reclamation emerged in the mid-1970's (Carter, 1990). As each mineral section of a mine is depleted, reclamation begins segmentally with overburden carried to an area under development. If sand and gravel producers must blend different aggregate sizes from the site, continuous reclamation is impractical from a production standpoint. Earth moving is an expensive business. Concurrent reclamation reduces the amount of land disturbed at one time and enhances the final soil quality rather than attempting reclamation at the end of all mining. Costs are lowered as equipment is still on site and less earth is moved.

Each movement of topsoil results in about 15 percent loss, and severe degradation occurs just in storage over time (Norman and Lingley, 1992). Traditionally, to avoid soil erosion or degradation, native seed mixes are spread over the disturbed area. Three seeding methods may be used. The first (1), a natural approach, has already been discussed. The others involve (2) bringing in clumps of soil containing seeds and plant material or (3) a technique termed flailing (English China Clays Int., 1997). Flailing involves collecting seed-bearing branches from the surrounding area, mixing the plants into a mulch, and spreading the seed mulch over the disturbed area. The advantage of these methods over commercially prepared seed mixes is a closer restoration to the local native flora.

As a reaction to landscape scars caused by coal mining, reclamation came to be legally defined as "back to approximate original contour." The recommendation of the Secretary of the Interior for reclamation was to correct damage to the lands and waters of the vicinity and leave the area in a usable condition

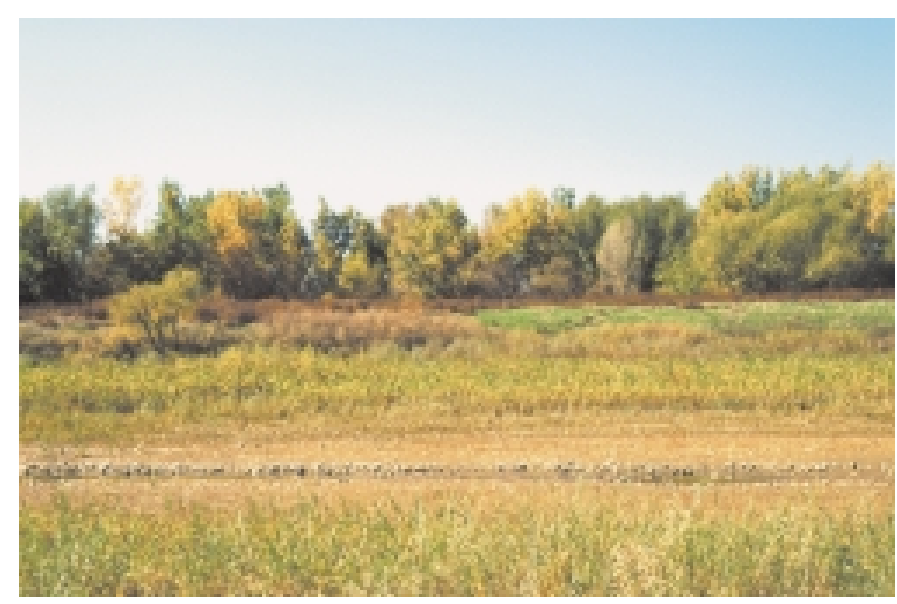

Figure 11. View west from within the WREN pit, east-central Fort Collins, Colo. Photograph by B. Arbogast.

(Simpson, 1985). Scientific data and budget constraints were not dealt with by public servants in reacting to the destructive practices of coal mining. Lawmakers reasoned in the 1970's that the best land use was to restore it to its original condition, but does that mean the way the land looked just before mining, before European settlers arrived, before Native Americans set wild fires to the Great Plains, or prior to the last ice age? In attempting to reshape the land back to its pre-mining form, billions of dollars would be required to move millions of cubic yards of earth to fill thousands of acres for esthetic purposes, and it would still not meet "original condition."

If returning land to its pre-mining form were taken practically, the WREN pit in Fort Collins, Colo., would become a cattle feedlot again rather than a natural riparian landscape. The final design was an attempt to cover the former mining site with native vegetation (fig. 11). During the 1920's, reclamation laws governed how mined-out land had to be restored to productive agricultural preuse. Recovery of land for cultivation of fruits, seed crops, and timber has been successfully demonstrated, mainly in rural areas; it may take years. Cherries, corn, alfalfa, and apples have been harvested on a former mined-out gravel pit in Ontario, Canada (Kuennen, 1983a). Exhausted sites have also been utilized for tree nurseries and saw timber. In the first years of reclamation for agricultural use, limiting harvesting and grazing is critical. Thorough planning is essential to restore the topsoil and subsoil to minimum thickness. A growing number of people are demanding that land reclamation be measured by how well the landscape functions, not by how well the landscape resembles the pre-mining form.

\section{Rehabilitation}

A rehabilitative approach targets social or economic benefits by reusing the site for public amenities, most often in urban centers. The disturbed site ends up with a specific land-use plan for people. In some cases, developers are allowed to expand their amenities into a mining buffer zone. Examples of rehabilitative uses include (West and Block, 1994):

Utilities (potable water, sewer, gas, and power lines)

Storm water drainage

Highway right-of-ways 


\section{Recreation-}

including horseback riding trails; baseball, soccer fields; a rod and gun club with skeet, target shooting; fishing in creek-fed ponds; meeting and banquet halls for social functions such as bingo, dances, weddings

The city of Hagen, West Germany, located its city hall on the site of an inactive quarry (Dietrich, 1990). Many of the natural rock outcroppings were left, and the interior/exterior surfaces of the building made use of the surrounding rock. In the U.S., golf courses have been built over abandoned quarries from New York to Florida, California to Texas. Some mining companies have even built golf courses while still operating, with years of reserves left. This frequently requires special permits for recreational use in a residential or commercial district. Townhouses, shopping centers, or industrial parks are other examples of a rehabilitative approach.

On the coast of Kenya, near Mombassa, an abandoned quarry illustrates a more comprehensive rehabilitation plan. Once barren land, with almost no underground water, it is covered with grass and trees. Rene Haller, a Swiss agronomist, introduced agriforestry, animal farming (including cattle, sheep, oryx, tilapia, and crocodiles), and tourism to the wasted landscape at low cost (Myers, 1990). Rather than introducing monocultures, he took an approach in which everything, from farm garbage to regrowth of wood fuel, is interrelated.

Quarries have a long history of being used for horticultural purposes from gardens and orchards to parks. Beginning in 1904, Butchart Gardens in British Columbia, Canada, was reclaimed from 50 acres of an exhausted limestone quarry to a premier botanical garden (fig. 12). Opened to the public in the 1940's, the site receives more than a million visitors each year. This grand, artificial landscape is only one in a long line of quarries reclaimed as gardens, esthetically pleasing to the public as cultural art, but ecologically not a copy of nature. More recently, the Memorial University of Newfoundland Botanical Garden, Canada, approved a former gravel pit for use as an arboretum.

Thorpe Park (near London, United Kingdom) is an amusement park developed on the site of an active sand and gravel operation (Dietrich, 1990). Such intensive interim use as a tourist attraction is unusual in the industry. Oakwood Lake, in the San Joaquin Valley, Calif., is a commercial waterslide park with a 6,000-seat amphitheater in a reclaimed aggregate mine (Mencacci and Carter, 1989). There are people with fond memories of swimming in quarries renovated with diving platforms or scuba diving facilities (Canham, 1986). In the 1950's, near northwest Toledo, Ohio, one exhausted limestone quarry/swimming hole even had an outdoor dance floor and orchestra shell where the big bands (including Tommy Dorsey and Benny Goodman) played. Rehabilitation is a frequent design approach in urban areas with large population centers.

\section{Mitigation}

Some mined areas have undergone major changes, either human or natural, after mining. A mitigation approach attempts to include scientific input to protect the environment and return these mined areas to beneficial use. Environmental data utilized
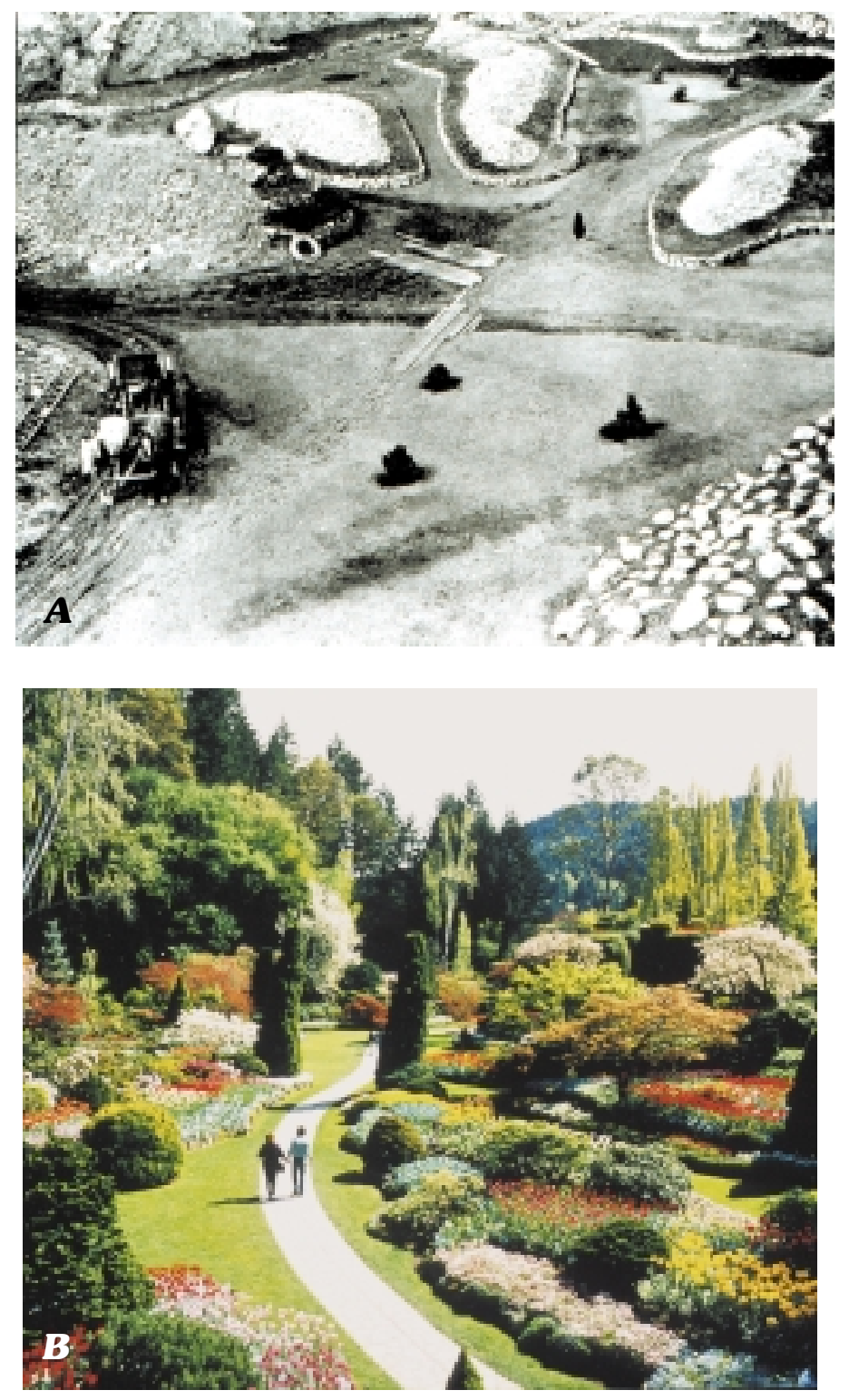

Figure 12. Before and after aspects of Butchart Gardens, Vancouver Island, B.C. Photographs courtesy of Butchart Gardens Ltd., Victoria, B.C. $A$, Historical photo showing the creation of flower beds in the sunken garden, circa 1912. B, The Sunken Garden-Spring.

in mitigation planning include geomorphic setting, watershed, viewshed, hydrology, soil and waste characterization, climate, vegetation, wildlife habitat, and historical.

Companies in California and the United Kingdom have used mined-out quarries as authorized landfills - and have sold the resulting methane for profit (Kuennen, 1983b). The future use of quarries for landfill is questionable given the need to protect ground-water aquifers. Some States have enacted bans on minedout aggregate pits for landfills; the concern is for ground-water contamination due to the permeability of sand and gravel floor surfaces. Excavated sand dunes are harder to reclaim due to steep slopes and lack of overburden. Resulting sand tips can remain barren for years without human intervention, so industry is focusing on research to improve the reclamation.

English China Clays, Int., developed the needed expertise in establishing vegetation by means of hydroseeding and the 
early grazing of sheep to build up soil fertility (1997). Hard rock quarries are more expensive to grade and yield steeper slopes but the design opportunities are extensive. Blasting the side walls to create talus (coarse angular rock fragments at the base of steep rock slopes) and sculpting the slope to blend with surrounding landforms aid in creating a more natural landscape. On quarry or pit sites, large stones and wood can be recycled for reptile and invertebrate habitat.

A mined-out site can be seriously degraded by illegal dumping. The Department of Defense and Atomic Energy Commission dumped contaminated debris into the 9-acre Weldon Spring Quarry (30 mi west of St. Louis, Mo.) for nearly 30 years (Department of Energy, 1996). Ground-water contamination spread toward well fields that supplied homes and industry throughout the area. Cleanup of the bulk waste began in 1989 by the EPA Superfund Program and the State of Missouri. Beginning in 1993, 120,000 cubic yards of contaminated soil, rock, and metal were removed to a temporary storage facility. This left more than 2 acres of quarry floor and up to $60 \mathrm{ft}$ highwalls (fig. 13).

High-quality clay soil is required to construct the permanent disposal facility and make it impervious to water. Nearly 2 million cubic yards of clay will be excavated from more than 200 acres of land in nearby Weldon Spring Conservation Area. In this case, the cleanup of one mine site requires the construction of another. What sounds like a fairly easy decision, to
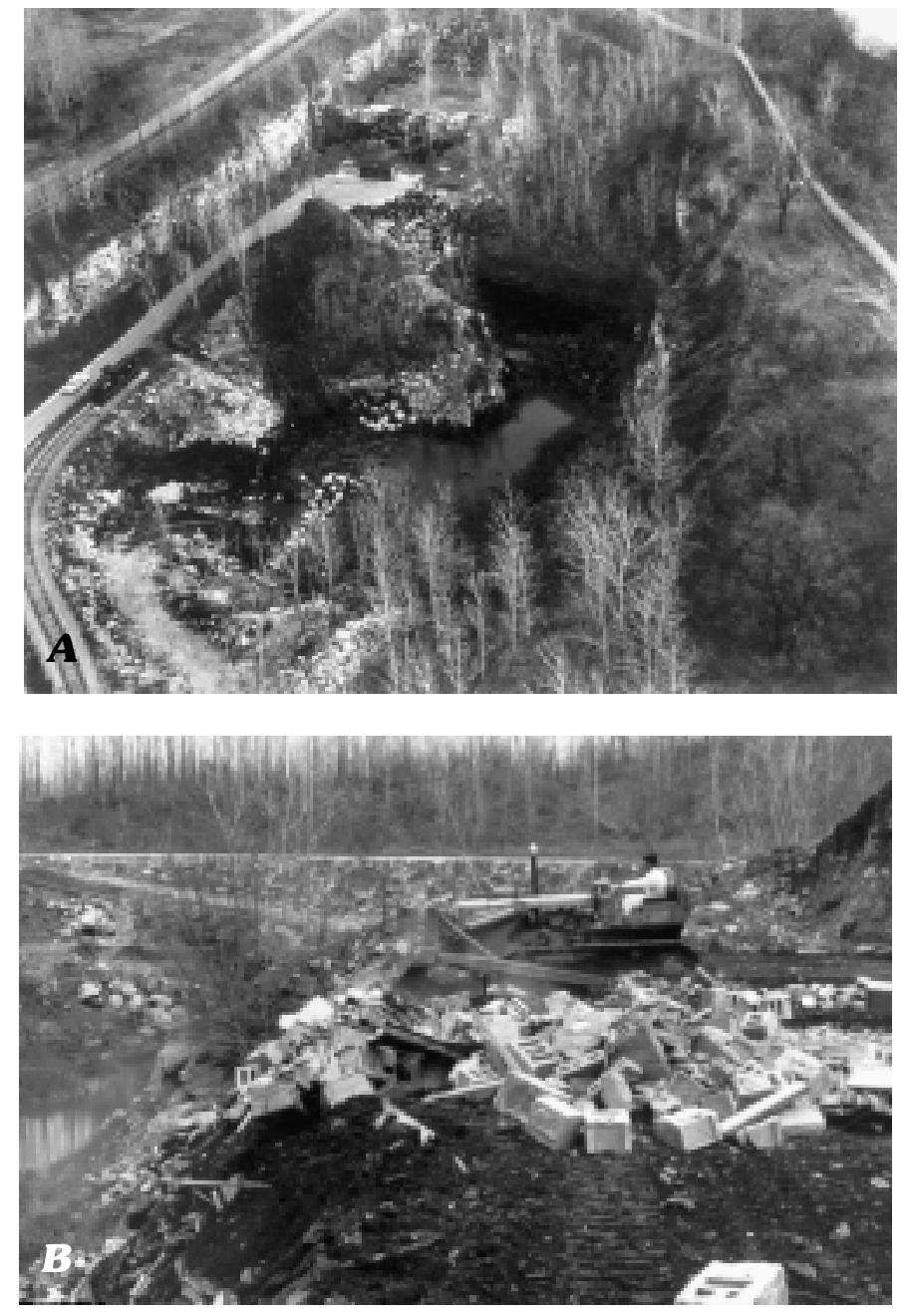

restore a quarry, became a draft plan requiring approval of the EPA and the State. One critical decision is whether to (1) plug the quarry on the upstream side for water containment or (2) let the water run through the quarry and continue ground-water remediation downstream.

Nature can also degrade mined lands. Over a 35-year period, Cooley Gravel Company extracted more than 26 million tons of aggregate from a site along the South Platte River, Colorado. Floods in 1965 and 1973 breached levees and changed river channels, with catastrophic impact on the land. Cooley reclaimed the land and donated 425 acres to the city of Littleton. Today, together with adjacent land dedicated by Littleton, South Platte Park is one of the largest wildlife parks within city limits in the United States (fig. 14). Cooley worked closely with a number of government agencies, including the South Suburban Park and Recreation District, Army Corps of Engineers, and Soil Conservation District. The design incorporated native seed mixes, trails, fishing along the South Platte River, and the opportunity for educational tours at the Carson Nature Center.

Efforts to mitigate the biological impact of mining include industry, State, and Federal agencies. States check for endangered or threatened species within an area proposed for mining. The Preble's meadow jumping mouse (Zapus hudsonius preblei) is listed as a "threatened" species under the Federal Endangered Species Act (Gerhardt, 1998). With the mice residing in moist lowlands of dense vegetation along the Colorado Front Range, there could be an impact on gravel operations close to waterways.

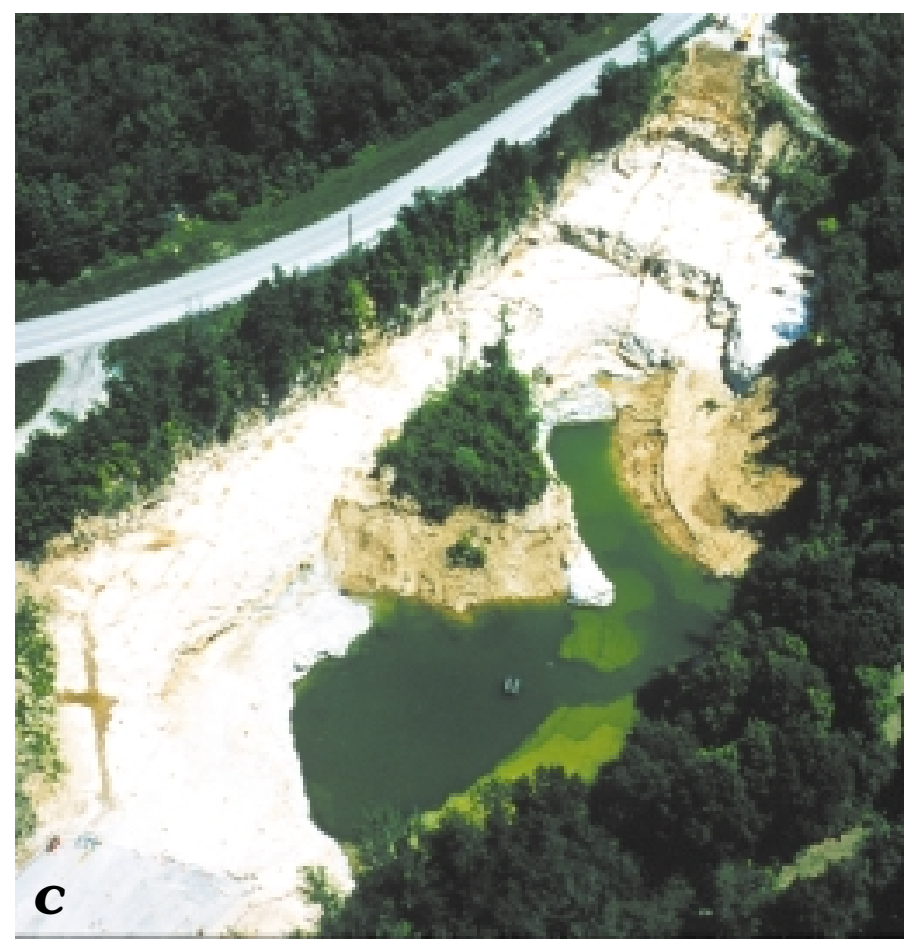

Figure 13. Quarry at Weldon Spring, Mo. Photographs courtesy of Morrison Knudsen Corporation, St. Charles, Mo. A, B, The visual effect of dumping operations from 1940's to1960's. Waste types included TNT/DNT, thorium, radium, and uranium. C, Excavated quarry basin. 
The Department of Geology and Mineral Industries in Oregon awarded the Oregon Concrete and Aggregate Producers Association for their work in improving salmon habitat. This was accomplished by

connecting off-channel ponds in the floodplain to provide rearing habitat for young coho salmon. Historic farming practices and urban development have eliminated natural backwater areas needed for migrating fish (Priem, 1997, p. 29).
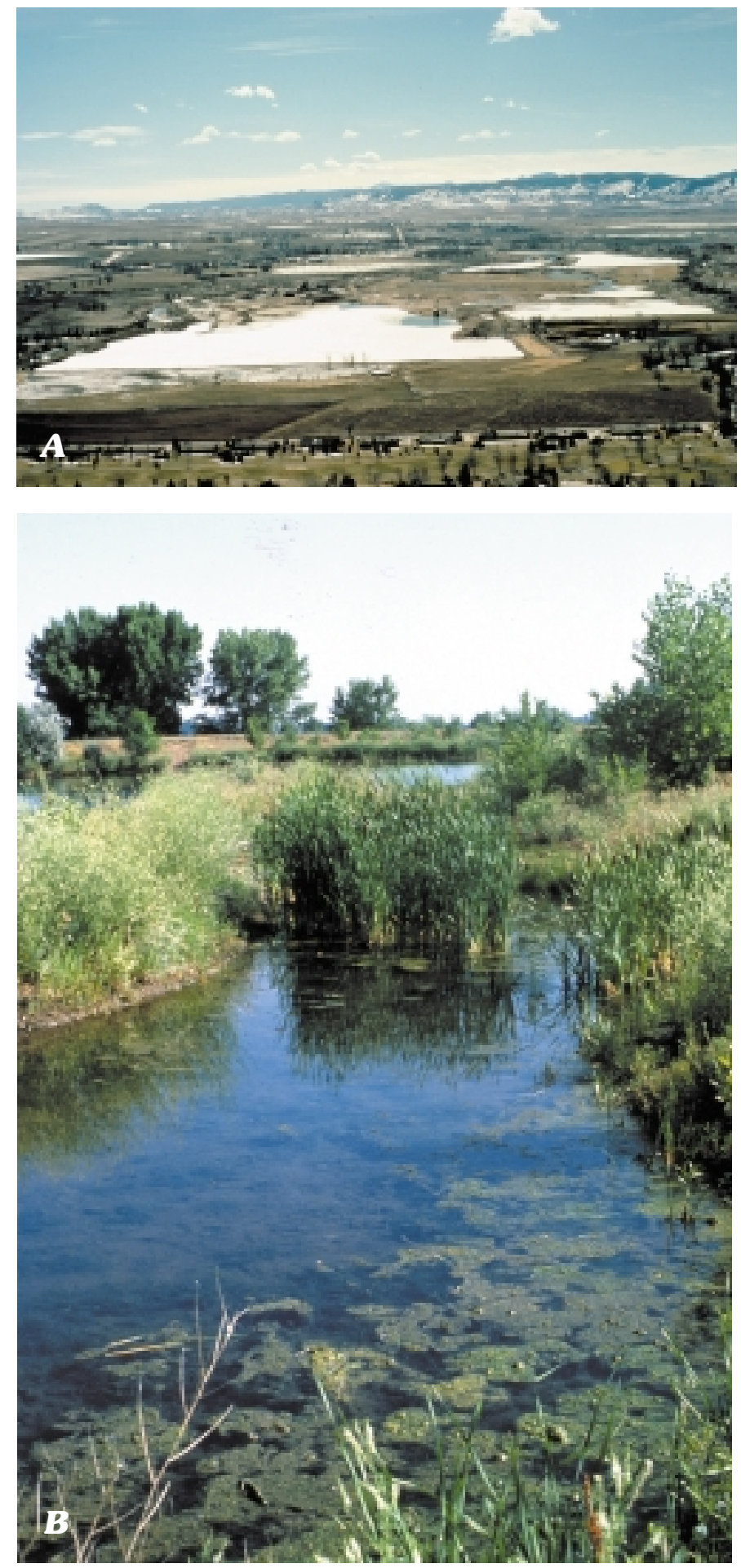

Figure 14. South Platte Park, Colo., formerly an aggregate mining site. Photographs courtesy of South Suburban Park and Recreation District, Littleton, Colo. A, Aerial view of South Platte Park, 1988. Photograph by Bill Bevington. $B, 10,000$ Trees Wetland Lake \#2, South Platte Park. Photograph by Raymond Sperger.
The Torrance Quarry, west of Pittsburgh, Pa., took steps to preserve the endangered eastern woodrat in cooperation with State officials (Anonymous, 1997). Woodrat habitat was not mined, and a run was constructed to provide shelter and connect two areas.

\section{Renewable Resource}

Mined-out land can be a source of renewable resources, or a place to process them. Renewable resource use is a complex issue; it implies that a project has environmental sensitivity and biological controls, and that it results in a reduction in resource/ energy inputs. Engler termed the approach sustainability, a concern with "the economics, conservation, and self-sufficiency of a waste disposal or processing site" (Engler, 1995, p. 18). Conservation land management is similar in requiring human input to maintain the renewable conditions. Nature has a hand in minor renewal of some alluvial sand and gravel deposits during floods. Thin or small deposits of sand and gravel can be moved downstream, where they collect into larger workable deposits from floodplains and terraces and become an important resource (Bliss and Page, 1994).

It is extremely difficult to implement a sustainable design for resource renewal on a micro-landscape scale. In a real sense most projects are not sustainable owing to an impact outside (output) the project site on the larger surrounding region. Land managers realize that incompatible land uses and artificial boundaries make it difficult to maintain the ecological integrity of a self-sustaining system even within large parks such as Yellowstone National Park.

Planners use three terms for sustainability at a local landscape level, where minimal land management allows succession to occur (Franke, 1996). The first term is protected-natural landscapes, wherein buffer zones are added to prevent human input affecting the local site. In mining reclamation, wide perimeter setbacks might be an example. The second term, modified-self-sufficient landscape, minimizes inputs and ecologically harmful outputs. At the Farm (Boulder, Colo.), reclamation of gravel mining pits to wetlands is an example (fig. 15). One of the most dramatic effects that human beings have on the ecosystem relates to loss of wetlands. During the period 1780 to 1990 , Colorado lost about half of its wetlands (Dahl, 1990). The Farm design incorporates oxbow lakes and more than 39,000 plants native to prairie wetlands in a

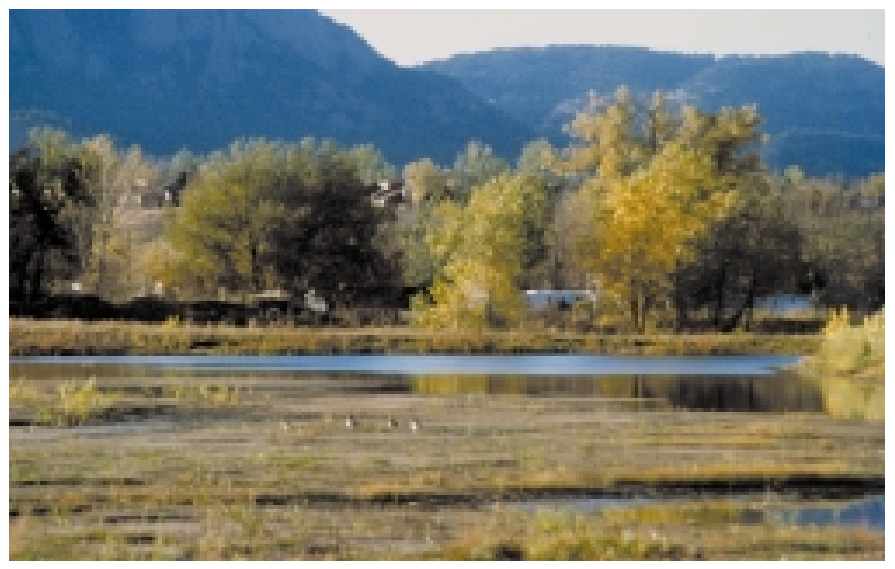

Figure 15. Restored wetlands from gravel mine site, Boulder Valley, Colo. Photograph courtesy of Western Mobile, Boulder, Colo. 


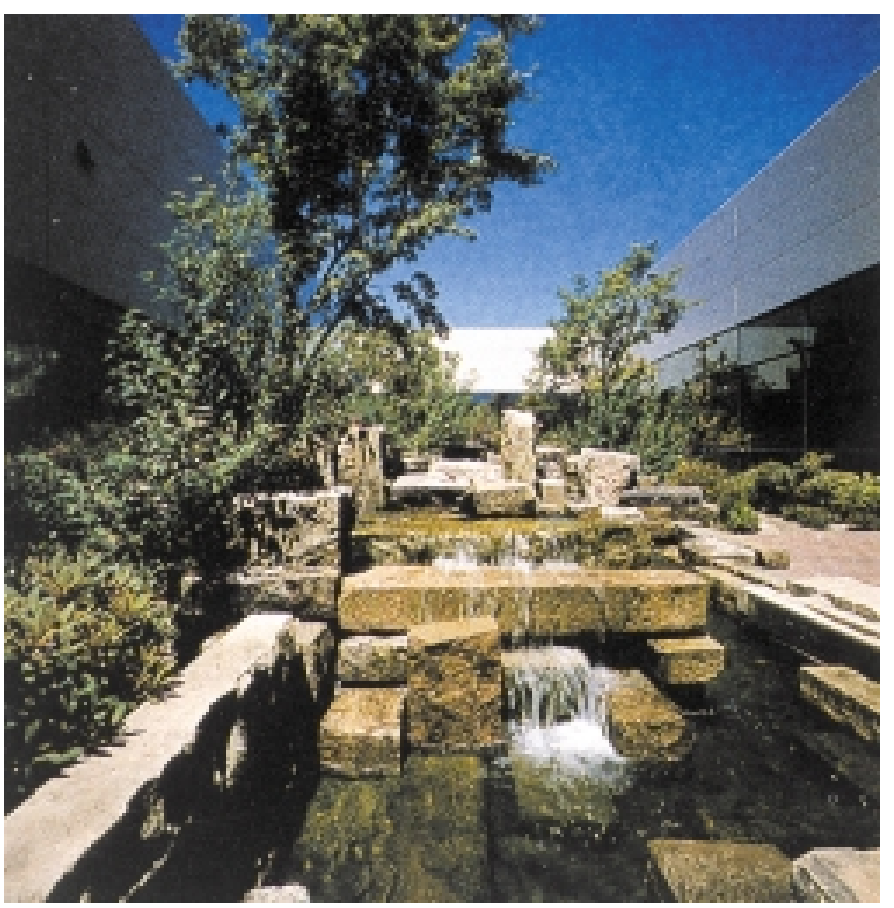

Figure 16. Sandstone fountain and pool, located in the central courtyard of NEC America headquarters in Hillsboro, Oreg., constructed of old building foundations and lintels. From Landscape Architecture (Washington, D.C., ASLA, 1989), p. 90.

100-acre site (Leccese, 1996). One important aspect of this project is the operators' recognition of their impact on natural riparian ecosystems and the renewal of water resources.

The third term, modified-redeveloped landscape, is applied to a system where ecological management is as important as financial profit. Silver Creek Materials, Fort Worth, Tex., is an example of such a system and has a composting operation on its sand and gravel site (Turley, 1995). Other examples of modified-redeveloped landscapes are mine sites where power companies dump tree trimmings, local dairies ship manure, waste haulers bring biodegradable materials, and local residents can purchase compost in bulk.

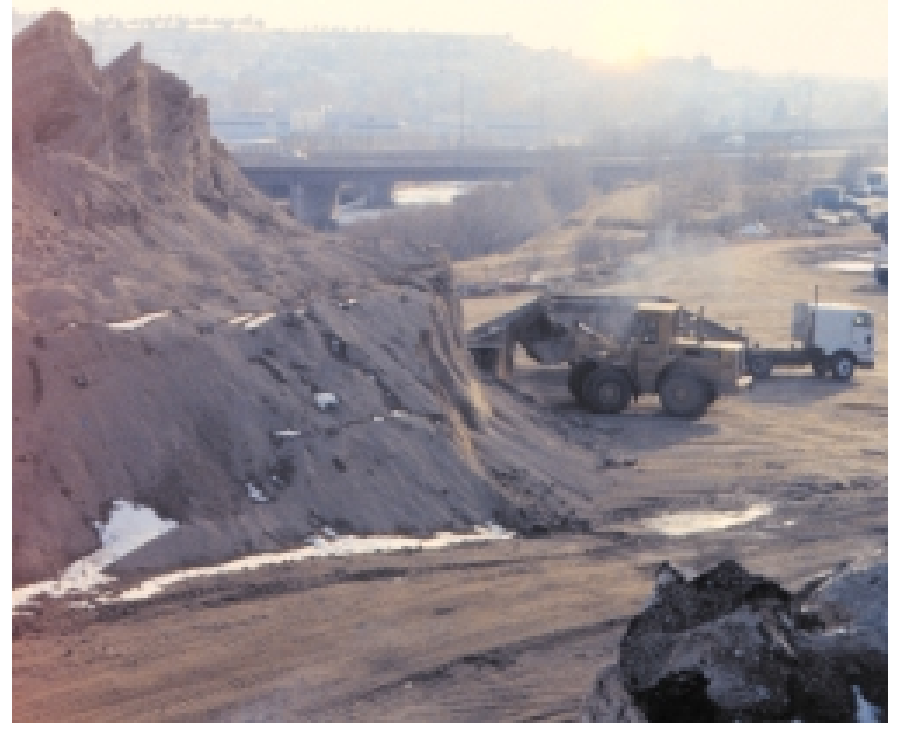

Figure 17. Recycled asphalt available for other projects (Recycled Materials Co.). Photograph by B. Arbogast.
The mining company is able to make use of equipment already on site, protect their investment, and continue to run a viable business. Where gravel pits are in farming or ranching country with resultant excess manure, a cooperative agreement between mine operators and neighbors could lead to on-site production of soil amendments. Transportation costs continue to be a big factor in the economics of renewable resources.

For some experts, a sustainable relationship with the Earth will only come about by controlling growth, reducing consumption of goods, and preserving diverse landscapes. Recognizing the limited supply of mineral resources and encouraging recycling efforts are beneficial steps. England and Wales have established planning guidelines, whereby one objective is to reduce the proportion of stone removed from land, from the current 83 percent to 68 percent, by 2006 (Richardson, 1995). A tremendous amount of construction material is wastefully landfilled and is an under-utilized resource. The current reuse of cement, building rubble, and macadam meets only about 10 percent of the demand for aggregate. Old building foundations, lintels, and broken pavement can be used to construct fountains, pools, and retaining walls (fig. 16).

Aggregate base course, screened rock, and structural backfill have been processed for highways, airport runways, hotels, and sports arenas. Unfortunately, recycling programs do not play a significant role in reducing consumption. Some mine operators contribute to reuse by saving a location for recycling of concrete, macadam, glass, and other resources (fig. 17). In many areas, there is a minimum fee to dump concrete and asphalt debris for recycling. Unless one is a large contractor and

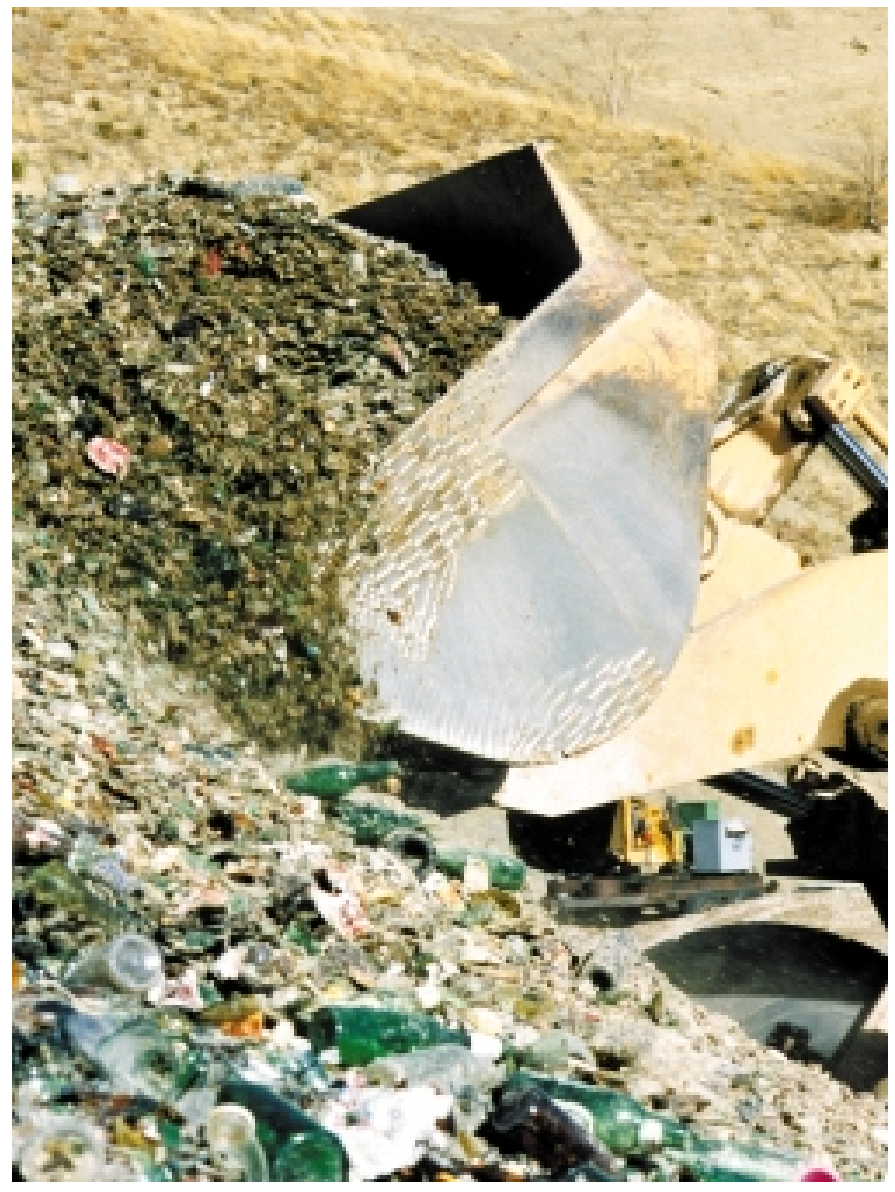

Figure 18. Stockpile at Western Mobile Boulder's Glass Crushing Center. Photograph courtesy of Western Mobile, Boulder, Colo. 
customer, the collection fee (from $\$ 12$ to $\$ 40$ a load) for disposal and handling is not waived. For the individual, recycling makes sense from an environmental standpoint. Depending upon sanitary landfill fees and hauling distance, the effort may or may not make economic sense.

Crushing asphalt and concrete on site for reuse can be of benefit in public works. Recycled Materials Co. (based in Arvada, Colo.) brings a portable processing plant, including crusher/pulverizer, conveyer, and screens, to projects for a fraction of the cost of disposal. Broken concrete (a magnet separates the steel for scrap), asphalt, and masonry rubble are crushed to specification, including State Department of Transportation requirements, with a typical price around $\$ 5$ per ton. Mobilization fees to bring a portable processing plant on site are extra and vary with scale of operation and distance to the site.

Mixed-color glass is also recycled as an ingredient in Enviro-Fill, a self-compacting, flowable structural fill for public utility works, first used in 1995 (fig. 18). The product (25 percent processed glass, 75 percent aggregate and flyash — a byproduct of coal-fired power plants), was developed in a public-private partnership with three organizations: Western Mobile, City of Boulder [Colorado] Environmental Affairs and Public Works

Department, and Eco-Cycle. Enviro-Fill is considered an environmentally friendly construction material and helps extend the availability of landfill space.

\section{Education}

In the educative approach, mining information is communicated through outreach, the desired effect being that citizens make informed choices about future land use. Europeans tend to be ahead of the U.S. in this regard, due perhaps in part to their limited available land. They also focus on esthetics as much as the functional after-use. For example, scientists in the United Kingdom have understood the importance of gravel pits as habitat for birds since the 1930's and 1940's. A 200-acre site of reclaimed land in Cambridgeshire, United Kingdom, is a nature preserve where more than 160 species of birds are observed. The ECC Quarries reclamation of a sand and gravel mine has been listed in "Sites of Special Scientific Interest" by the Nature Conservancy Council (Carter, 1990). At the Caistron nature preserve (created by the Ryton Sand and Gravel Group) masonry and wooden blinds await visitors viewing wildlife (Dietrich, 1990). ARC Ltd. (Buckinghamshire, United Kingdom) has researched reclamation of sand and gravel pits for nature conservation in an open-air experimental laboratory for more than 20 years.

In the U.S., The National Stone Association (NSA) and American Association of Landscape Architects (ASLA) jointly sponsor an Annual Landscape Architecture Student Competition, aimed at giving aggregate operators new ideas on reclamation and beautification. Unfortunately, the NSA does not keep historic records of the winning entries other than names. Judged on creativity, practicality, and design, winners earn cash prizes and an opportunity for feedback from the producers. The first place winner for 1991 was published in Landscape Architecture (fig. 19) and provided an environmental retreat "for the gathering of people to confront and resolve pressing environmental issues for the 21 st century" (Thompson, 1991, p. 79). These tantalizing projects have been going on for 22 years and are worthy of being

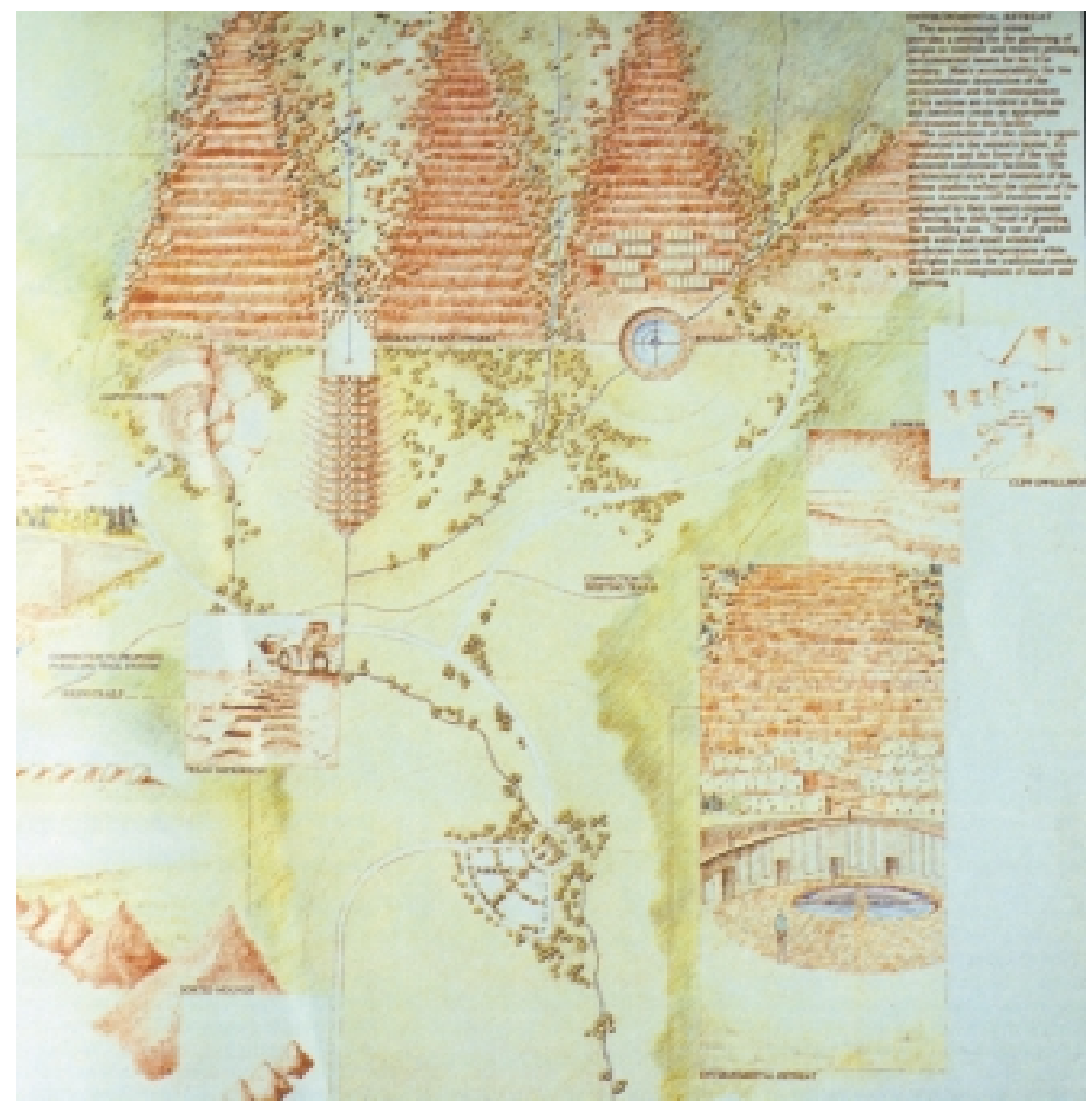

Figure 19. NSA/ASLA Student Competition First Place: Linda Attaway, Mary Dewing, University of Colorado at Denver. From Landscape Architecture (Washington, D.C.: ASLA, 1991), p. 79. 
archived for future reference. A yearly publication of private, governmental, and industry awards for reclamation efforts would raise public awareness of mining land stewardship.

A small (12-acre pit) mining operation cited as an example of land stewardship and community service in the U.S. is Davis Sand and Gravel, Sequim, Wash. (Smith, 1997). Geology and forestry students from the local college tour the site as part of their studies, and the company donated time and money to the conservation district and high school. At this site, introduction of wildflowers and trees followed a planting of cover crops; nursery plants are irrigated with recycled water from ponds that provide waterfowl habitat. Runoff water is collected in the ponds and tested monthly for $\mathrm{pH}$.

On another operating scale is a mined-out 640 -acre gravel pit purchased by Pierce County, Wash., that includes 2.5 miles of Puget Sound shoreline (Thompson, 1997). Utilizing biosolids generated from an adjacent wastewater treatment plant, the county, in cooperation with the University of Washington, is developing a research and demonstration program for reclamation of the site.

The Nature Conservancy restored a 65 -acre gravel pit next to the Bluestem Prairie Preserve, Minn., as a test site (fig. 20 is an example of the prairie ecosystem). The reclamation was

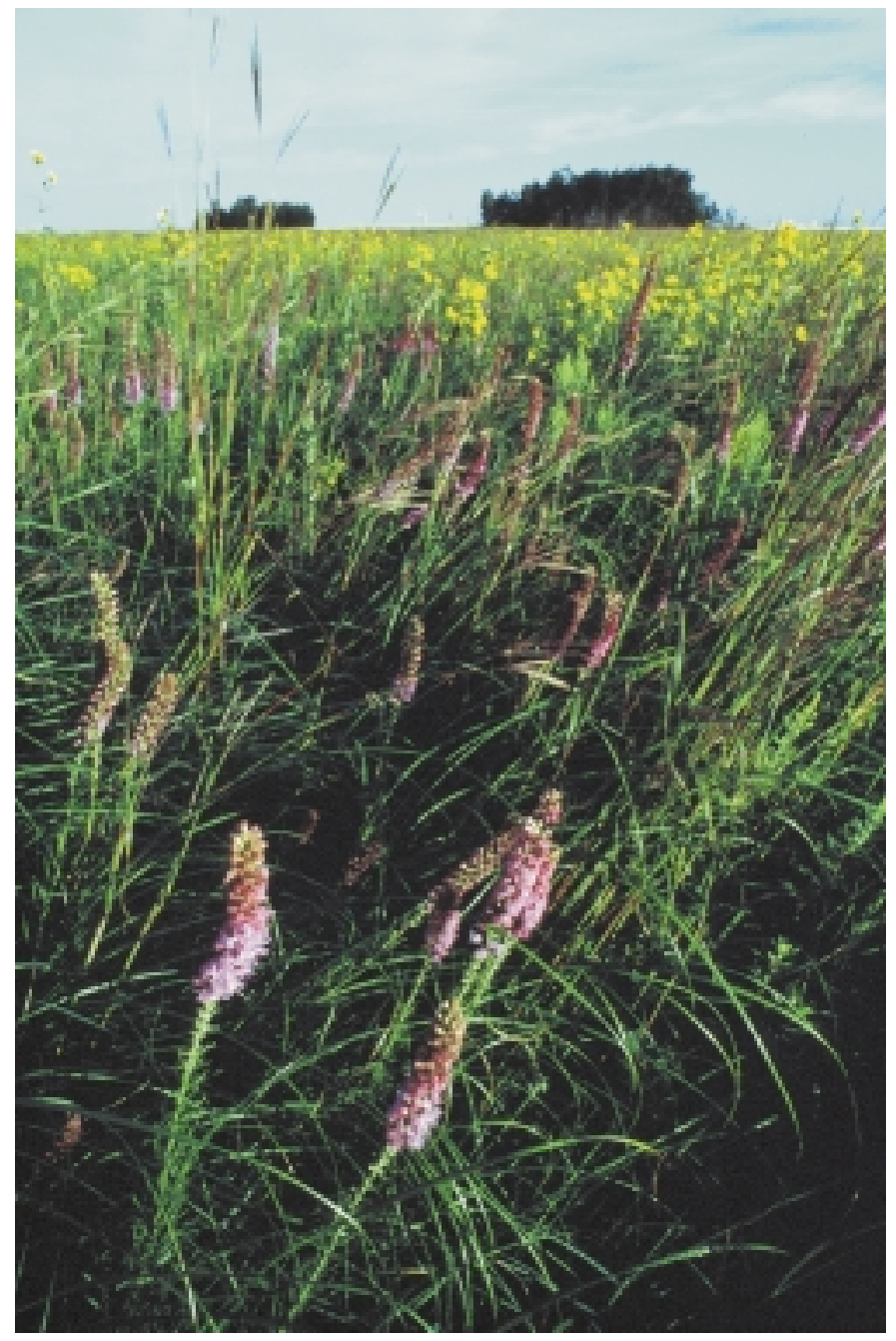

Figure 20. Complex vegetation of the Minnesota prairie. Photograph by (C) Richard Hamilton Smith, St. Paul, Minn. expensive (due to burning, spraying for exotics, contouring) and lacks native biological diversity (Breining, 1996). Costs would have been reduced if land had been graded while equipment was still on site for operations, but the project is still considered successful by the Conservancy. The Minnesota Department of Natural Resources is restoring two gravel pits in Buffalo River State Park with locally harvested native prairie grasses.

In Alaska, the NPS Geologic Resources Division is studying a comprehensive sand, rock, and gravel resource plan for Katmai National Park and Preserve. The intent is to achieve maintenance goals while reducing impacts to natural resources (Ziegenbein, 1997). This project exemplifies parks' need to quantify existing and new resource needs and assess environmental impact from extraction. Among 50 existing sand, rock, and gravel pits (40 are abandoned) at Katmai, only 1 is being considered for long-term use. The site is being considered for reopening because it is naturally well hidden and contains quality material. One long-term plan is to mine large stockpiles (20-year supply) and reclaim the slopes immediately. The stockpile is then left for future use, and the cost of keeping equipment on site is minimized. One proposal is to use the gravel site as an interpretive opportunity during bus tours. The goal is to raise visitor awareness that their presence requires infrastructure and thus mining.

Another example of educational outreach comes from Albuquerque, N. Mex., where Western Mobile replaced the grass lawn at its corporate headquarters with a xeriscape garden (fig. 21). The ground cover, parking lot, pavement, signage, and building make use of aggregate and both help educate people and promote the industry's products. The garden requires about $10-20$ percent of the water previously needed and is open to the public.

Research by the industry includes plots planted and tested by Angell Brothers, Oregon, for revegetation techniques and species selection over the next 20 years (Priem, 1997). Scientific investigations have led to publications regarding the following: Optimal soil preparation and compacting Appropriate landforms

Treatment of overburden (topsoil and subsoil)

Runoff water, subsurface drainage

Waste used as backfill, methane gas production

Vegetative mixtures, plant species for best survival and vigor

Specific research and demonstration areas within the U.S. on mined land reclamation need to be preserved and listed. Similar to the National Register of Reclamation Research and Demonstration Areas on Mined Land (Ashby, 1992), the proposed publication would cover nonmetallic mining. Ashby's 1992 publication emphasized lands mined for coal.

\section{Art}

An artistic approach is one where the site is celebrated as a work of beauty and unique experiences. Engler (1995) categorized the approach as celebrative; people can become fully aware of the connection between the production of an item and their everyday lives. One pioneer in the earthworks-as-art movement was Robert Smithson. Smithson made field trips to abandoned quarries and experimented with the sculptural qualities of earth, calling such projects abstract geology (Bourdon, 1995). He proposed, "Art can become a resource that mediates between the ecologist and the industrialist" (Bourdon, 1995, p. 


\section{To A Landscape That Showcases Southwestern Plants, Trees and Aggregate...Plus Conserves Water!}

$\boldsymbol{A}$

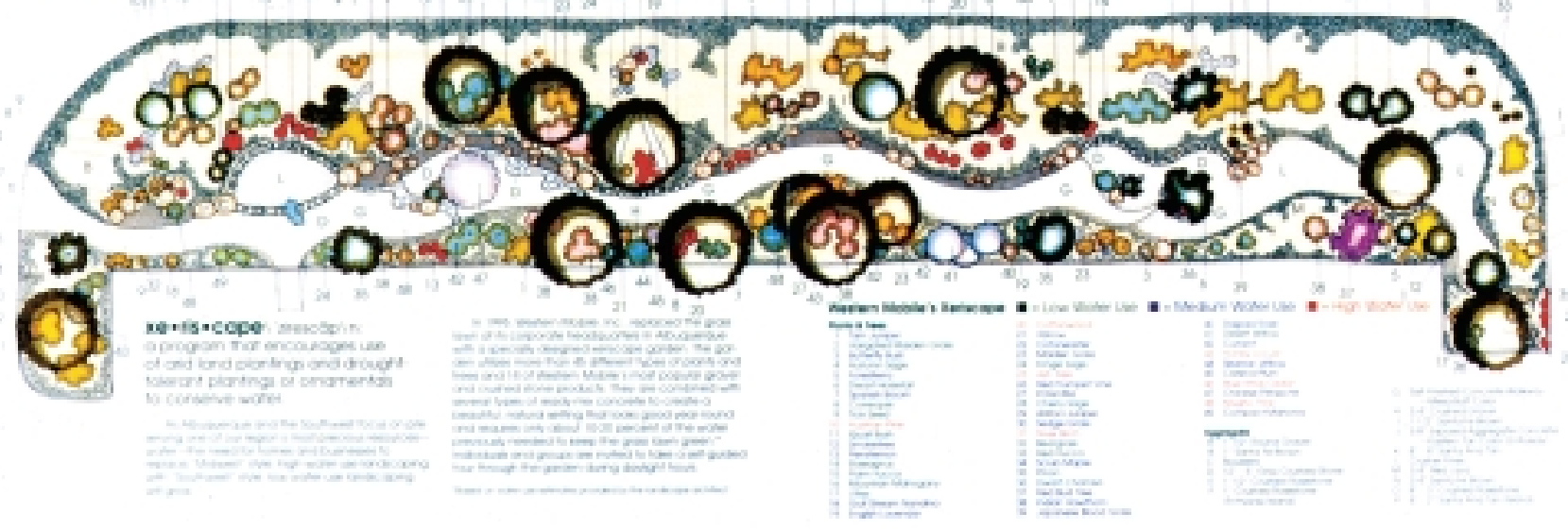

Figure 21. Western Mobile's xeriscape garden in Albuquerque, N. Mex. Courtesy of Western Mobile. A, Plan showing vegetative scheme. $B$, View showing relationship between pedestrian walkways and "borrowed landscape" of native plants and aggregate.

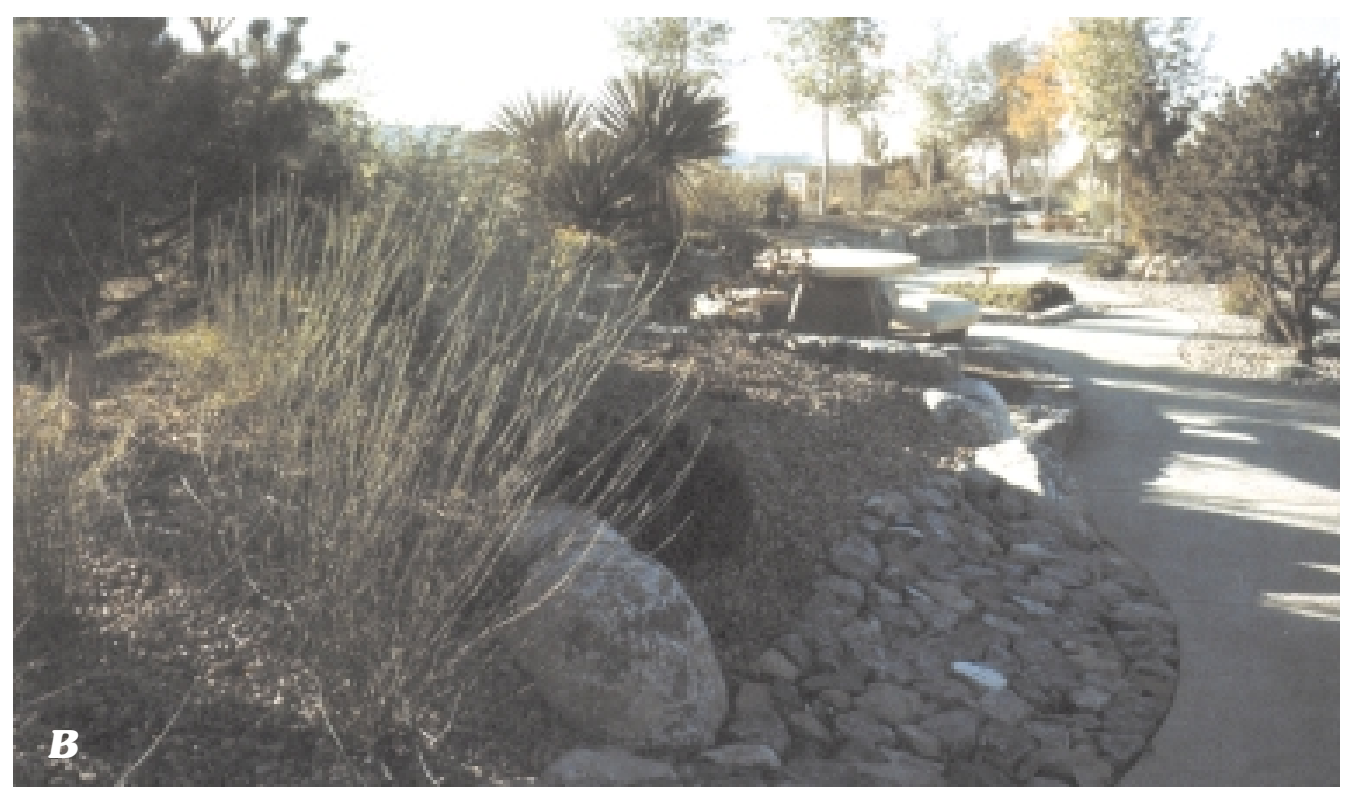

225). This report examines Smithson's "Broken Circle," Parc des Buttes-Chaumont, Aexoni Quarry, "Opus 40," and "Untitled (Johnson Pit \#30).'

The public Parc des Buttes-Chaumont in Paris (circa 18641869 ) is "the most dramatic early example of the art of landscape to re-create shape and form from apparent waste" (Jellico and Jellico, 1987, p. 257). Designed by Adolphe Alphand, the park was built upon old quarried limestone and gypsum pits, abandoned gallows, a sanitary sewage dump, and a mass grave. After reclamation, Parisians could stroll "aimlessly while observing the city's changing physical and social structure" and appreciate "artistic urban accomplishments" (Meyer, 1991, p. 19). Four grass mounts and an island were sculpted from the quarry with infrastructure including iron bridges, cafes, gatehouses, and a railroad (fig. 22). The mounts presented different panoramas of the urban landscape, including Montmartre. The site's geology was celebrated with a limestone cave, including artificial concrete stalactites. From a historical standpoint, the subsurface structure of the quarry is "preserved" in a grotto complete with an engineered waterfall. Alphand superimposed the technology of his time, using concrete and metal, into a park meant to reflect that culture, not as a recreation of nature. Views of the built environment were important —walking was to be the primary recreation.
A sculpted quarry at Aexoni, Greece, celebrates music and dance, while the natural landscape is acknowledged, thus expressing the Greek philosophy of the unity of all things. Completed by the local municipality and Ministry of Regional Planning and

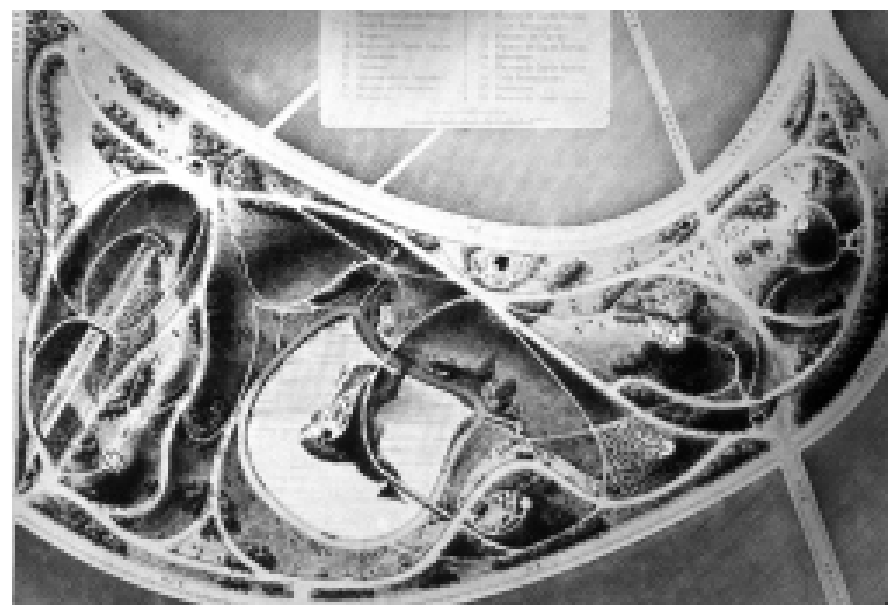

Figure 22. Parc des Buttes-Chaumont, Paris. From Les Promenades de Paris (1867-73) in The Landscape of Man (Jellicoe and Jellicoe, 1987), p. 257. 


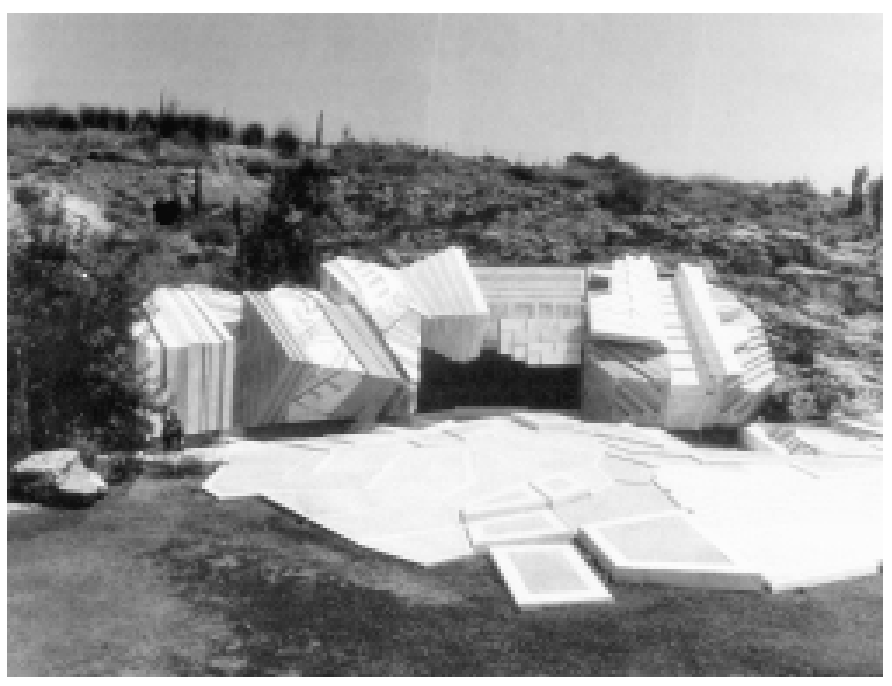

Figure 23. Aexoni Quarry, Greece. Photograph by Dimitri Ualapodas. From Golanda (1994, p. 145).

Environment in 1992, the functional end use is to accommodate performing arts and exhibitions. This can also be viewed as an example of the rehabilitative approach. Regional vegetation was planted, and sculptural forms relate to adjacent rock formations (Golanda, 1994). Golanda expressed the floor plane and backdrop of the stage design as an impression of excavation - a cave (fig. 23). For today's generation it is more reminiscent of a space station's docking platform. In an abstract sense one can feel the intended spatial imagery and varied topography, but whether it recreates a pictorial quarry is open to question. Quarries can make dramatic amphitheaters. One of the earliest and most famous Italian Renaissance amphitheaters was modeled about 1590 in the Boboli Gardens of Florence, Italy. The quarry had provided stones for the Pitti Palace.

In the Catskill Mountains, near Woodstock, N.Y., is an old stone quarry (abandoned, ironically, due to the increasing use of concrete). Using traditional 19th-century tools and a pickup truck, Harvey Fite created display areas for his Maya-influenced sculptures through the 1940's and 1950's (Dalton, 1985). In the early 1960's, he realized the quarry was a work of art in itself and moved the sculpture to adjacent lawns. Calling the quarry "Opus

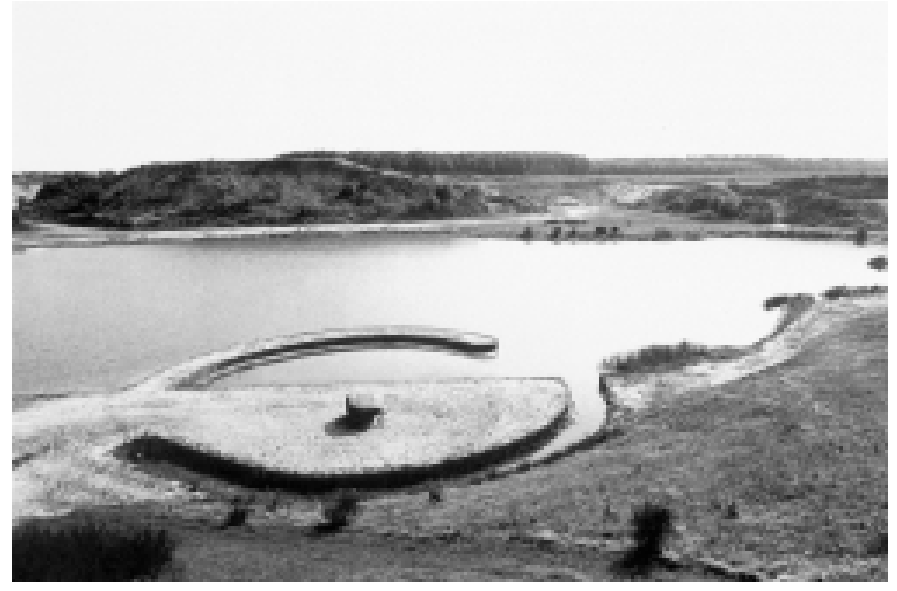

Figure 24. "Broken Circle." Photograph by Pieter Boersma. From Bourdon (1995, p. 214).
40," Fite constructed multiple ramps, terraces, steps, and pools in strong geometric forms reminiscent of a hardscape Italian garden. Today, weddings and concerts are held at the site.

A sand pit and body of water were utilized by Robert Smithson in 1971 to create a more open sculptural form. A circular jetty and canal, titled "Broken Circle," was constructed in the Netherlands as part of an international art exhibition (fig. 24). About 140 feet in diameter, the symmetrical landform suggests yin and yang, inviting human passage. The earthwork also evokes images of dikes and polders that are the backbone of Dutch landscape. Smithson became aware of the constant changes in nature and believed the changes could interact with and enhance art on disturbed land. Flooding, evaporation, soil chemistry, and plant life would modify earthwork and site alike.

Another site-specific earthwork is "Untitled (Johnson Pit \#30)" by Robert Morris, a minimalist sculptor (fig. 25). Sponsored by the King County Arts Commission, Wash., Morris formed an earth sculpture from an abandoned 4-acre gravel pit in 1979, emulating a strip mine with concentric terraces (Morris even cut down fir trees that had been growing on the pit rim). Nearby residents complained that the site was simply being exploited once more. Morris replied,

***the selling point was, is, that the art was going to cost less than restoring the site to its 'natural condition.' What are the implications of that kind of thinking*** that art should be cheaper than nature?***The most significant implication of art as land reclamation is that art can and should be used to wipe away technological guilt*** Will it be a little easier in the future to rip up the landscape for one last shovelful of non-renewable energy source if an artist can be found (cheap, mind you) to transform the devastation into an inspiring and modern work of art?*** It would seem that artists participating in art as land reclamation will be forced to make moral as well as aesthetic choices. (King County Arts Commission, 1979, p. 16.)

For those who want to know what the site means, Morris replied, “*** it does not seek control through explanation. That it offers the freedom to experience and question is not an opportunity that its audience always welcomes." The critical stance of Morris toward land disturbance, and his decision not to design an idyllic place, is understood a little better today than it was 20 years ago.

A 1997 renovation of the site involved concessions to address residents' concerns: more accessibility, interpretive materials, fencing and gated parking, improved drainage, and the rotted tree stumps replaced with "ghost trees" composed of pressed cedar.

\section{Integration}

The combination of art and science in a "human-nature ecosystem where work and leisure coexist" is an integrated approach (Engler, 1995, p. 22). Ideally, these become spaces of esthetic merit and utility, fulfill recreational needs, protect fragile ecosystems, and relate to their unique cultural context (Rainey, 1994). Combining art with science has been ridiculed by professionals on both sides. Scientists complain of artists being imprecise, "touchy-feely," subjective, making poor use of scientific information. Artists retort that scientists are narrow minded, too specialized, and out of touch with esthetics. Designers need information in a user-friendly format and layperson terms. The public often 

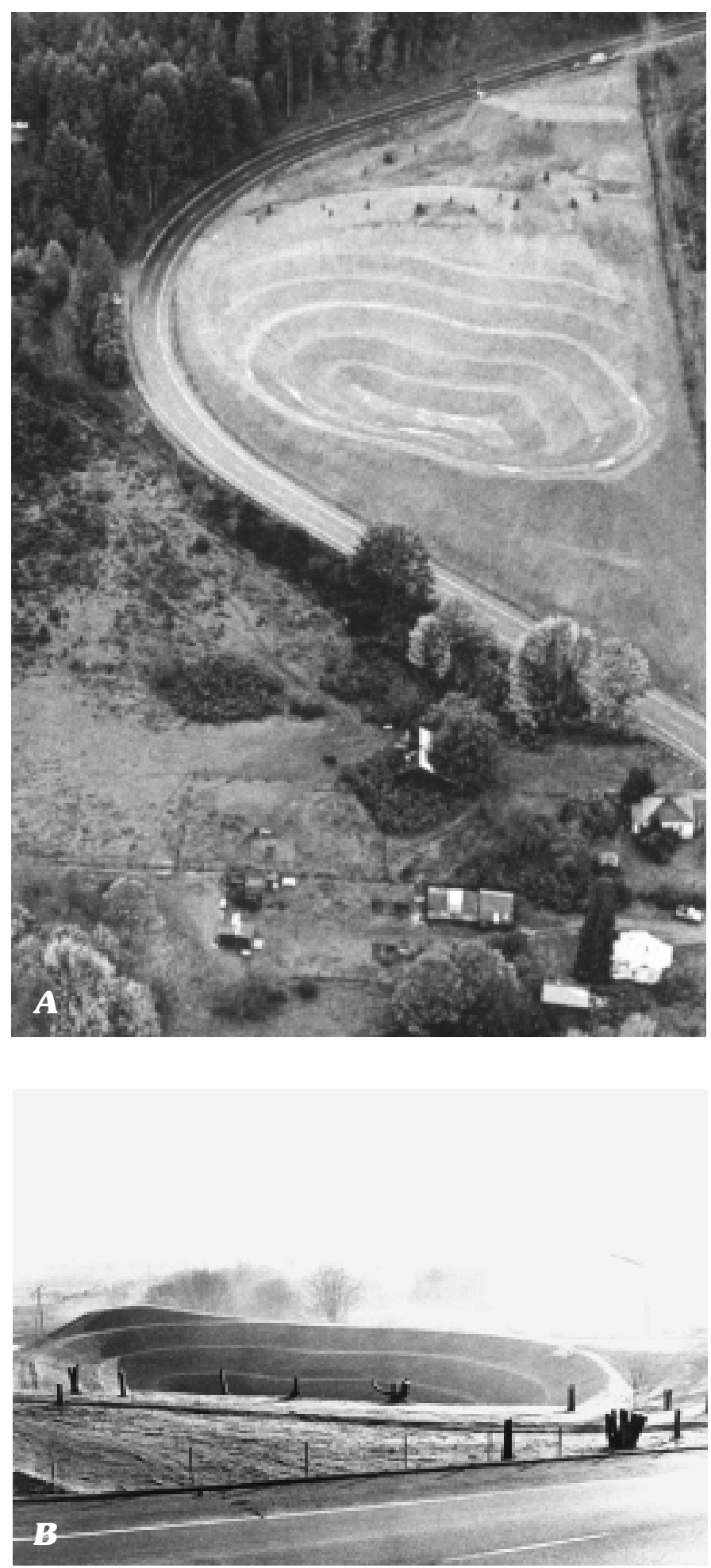

Figure 25. "Untitled (Johnson Pit\#30)." Photographs courtesy of the King County Arts Commission, Office of Cultural Resources, Wash. A, Aerial view showing constructed descending concentric benches, cleared of trees and planted in rye grass. $B$, Perspective view from highway.

considers both scientists and artists elitist and isolated from the community they are supposed to serve. There is a common ground where all sides need to meet, understand each others' limitations, and take mining reclamation to the next level. To address siting and reclamation problems in meaningful ways will require an integrated approach. Creating relationships between scientists and artists, merging earth science information with design principles, and integrating human perception is a new way of doing business. An example of this common ground is in France-a multi-disciplinary team consisting of a departmental architect, two representatives of the associations for the protection of the environment and nature, as well as heads of the mines, agriculture, public works, health, and social surveys make up a commission to examine quarry sites (Arnould, 1994).

Oregon's State Department of Geology and Mineral Industries created a Reclamationist of the Year award for individuals who go beyond State guidelines. The first recipient of the award was Paul Ruff, a lead equipment operator with Rogue Aggregates, who typifies the successful blending of art and science. Operating his bulldozer blade as an "artist's brush" (Priem, 1997), Ruff moves earth in nature's own style. He created sensuous landforms with irregular slopes, islands, complex pond edges, and diverse habitats, while conserving large trees. Priem's article characterized Ruff as having an unusual combination of artistic talent and heavy equipment experience that gets industry's job done efficiently while acknowledging environmental needs.

In the past, exotic or naturalized plant material was used extensively in reclamation schemes. This mindset continued because of lower cost and short-term goals such as erosion control and environmental tolerance (for example, drought or flood). Products of this type used to stabilize the soil include fibrous blankets, bog mats, coir logs, and fascines (Stein, 1997). Coir logs are made of coconut fiber and used in shallow channels; fascines are bundled wands of living wetland shrubs placed along the stream bank. Using native plants with the goal of greater diversity is difficult given the lack of nursery stock, low availability of seed, and higher cost. Consultants are beginning to specialize in revegetation plans with native flora (including rare and endangered plants) and establishment of appropriate ecosystems - such as wetlands, riparian forest, and savanna (Habitat Restoration Group, 1997). Native vegetation provides an important balance and esthetic value to the landscape.

Perhaps there will be a return to the neighborhood swimming hole, prairie grasses, and (or) recycling plants in abandoned pits. If a community has a sense of need for the reclamation enduse, approval for mining has a better chance. Three representatives of the integrated approach are (1) the Clay County Beach Ridges Forum, (2) Quarry Cove, and (3) "Effigy Tumuli."

A portion of Minnesota has native tallgrass prairie over gravel resources. By addressing potential resource problems in both the macro and micro landscale before serious conflict arose, the Clay County Beach Ridges Forum showed people (landowners, gravel producers, conservationists, government agencies) that their common interests are stronger than their different viewpoints. Selected viewpoints expressed in a report (Clay County Beach Ridges Forum, 1997) include:

- Maximize utilization of aggregate resources (the concept being to minimize land surface disturbance by exhausting the resource on an approved site by mining deeper and using high quality aggregate resources in higher quality products when feasible)

- Promote aggregate recycling (including a public information fact sheet)

- Consider aggregate resources in future land-use decisions throughout the county 


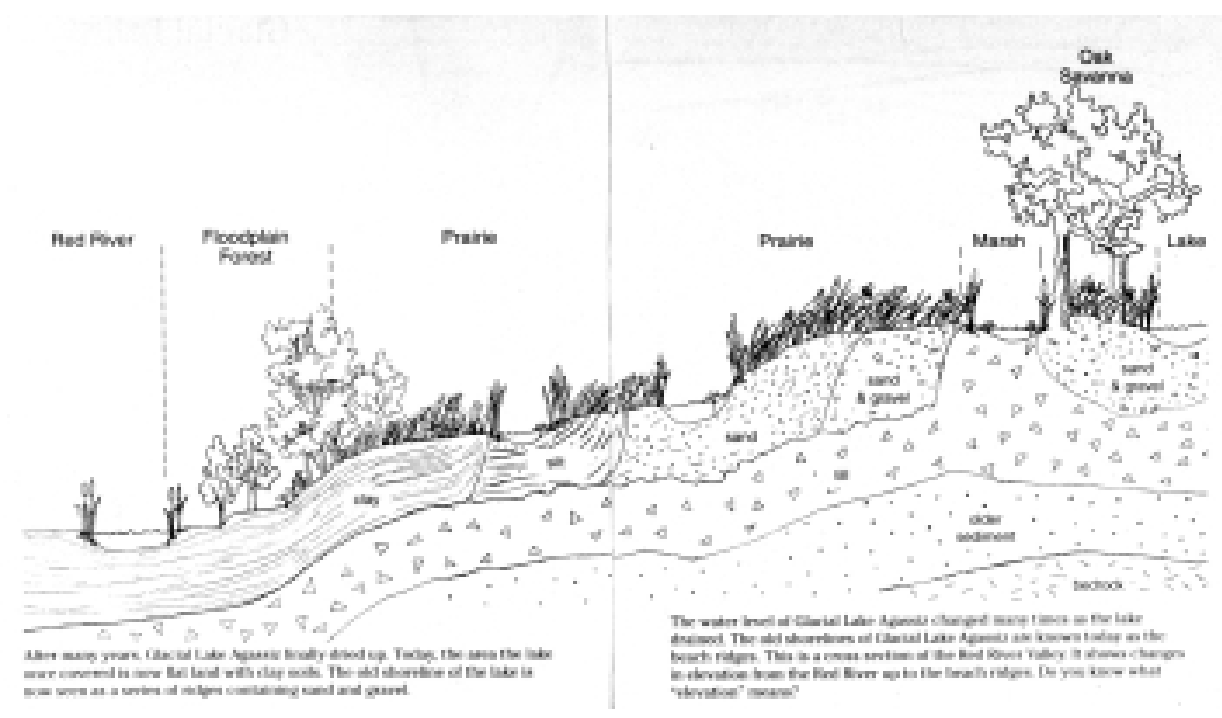

Figure 26. A tool "in teaching our children about working in partnership to achieve balanced natural resource management." From Lake Agassiz Beach Ridges-A Coloring Book for Children, courtesy of Minnesota Department of Natural Resources, 1997, p. 4-5.

- Provide incentives through the permitting process to avoid native prairie (one suggestion is to expedite the permitting process for proposals sited outside of prairie)

- Minimize development of new haul roads across prairie

- Use prairie grasses and forbs for gravel pit reclamation whenever possible

The Forum believed that it was also important for children to understand both the economic and natural value of the county's gravel and prairie resources - the result was a coloring book for children, "Lake Agassiz Beach Ridges" (1997b) (fig. 26).

Moving from the prairie to the Oregon coast: Quarry Cove is the first quarry converted into a man-made tidal zone fed and nourished by wave action (Thompson, 1996). Developed by the Bureau of Land Management, the site is wheelchair accessible, provides a variety of wildlife habitats, and is expected to have species diversity comparable to a natural tidal pool within 5 to 10 years (fig. 27). Graduate students in marine biology are conducting research, and visitors can view nature taking its course as marine life invades the area. It is an exciting example of an

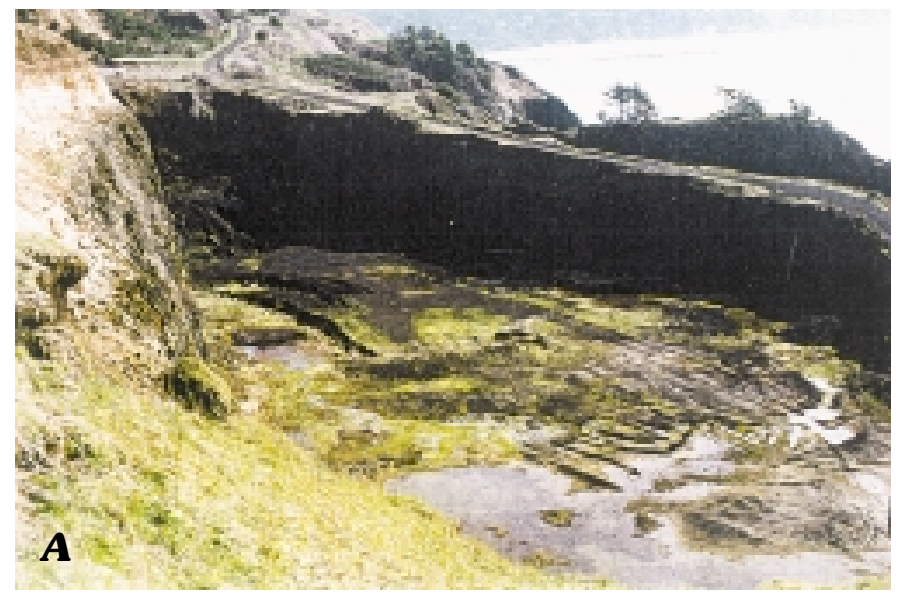

exhausted site becoming a "natural" biological laboratory with valuable outreach to the community.

On a larger architectural scale is a design by sculptor Michael Heizer in Buffalo Rock State Park, near Ottawa, Ill. Sited on land disturbed by coal mining, the reclamation plan celebrates the region's history of Indian burial mounds by incorporating earth shapes or tumuli-water strider, frog, turtle, snake, and catfish (Massie, 1985). The five sculpted animals (the snake is $2,070 \mathrm{ft}$ long and $18 \mathrm{ft}$ high) are visible to visitors on the ground and to air and boat traffic (fig. 28). Located on a sandstone bluff above the Illinois River, the 150-acre outdoor work was a cooperative effort by Ottawa Silica Company, a nonprofit organization, and State and Federal governments (Illinois Department of Conservation, 1997). The artist minimized expensive earth moving by studying existing mine site topography for hidden forms. Named "Effigy Tumuli," the project includes treating millions of gallons of acid water, neutralizing acid spoil, and seeding with wildflower and grass. Although this instance concerns a coal mine, reclamation can be tailored to include landform sculptures as demonstrated

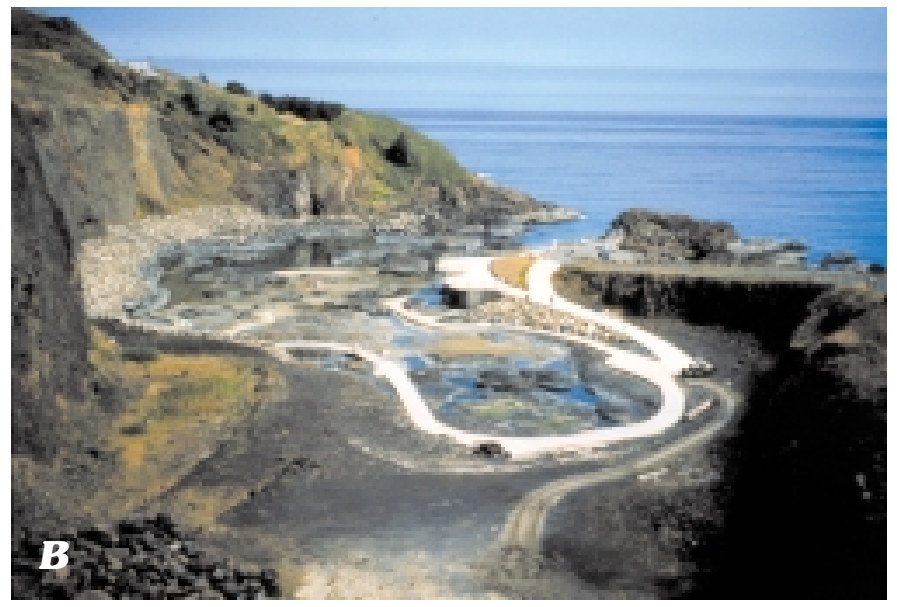

Figure 27. Quarry Cove, Yaquina Head Outstanding Natural Area, Newport, Oreg. Photographs courtesy of Bureau of Land Management, Salem District. $A$, View of worked-out quarry. $B$, Transformed cove at low tide; quarried below sea level with site open to the ocean. 


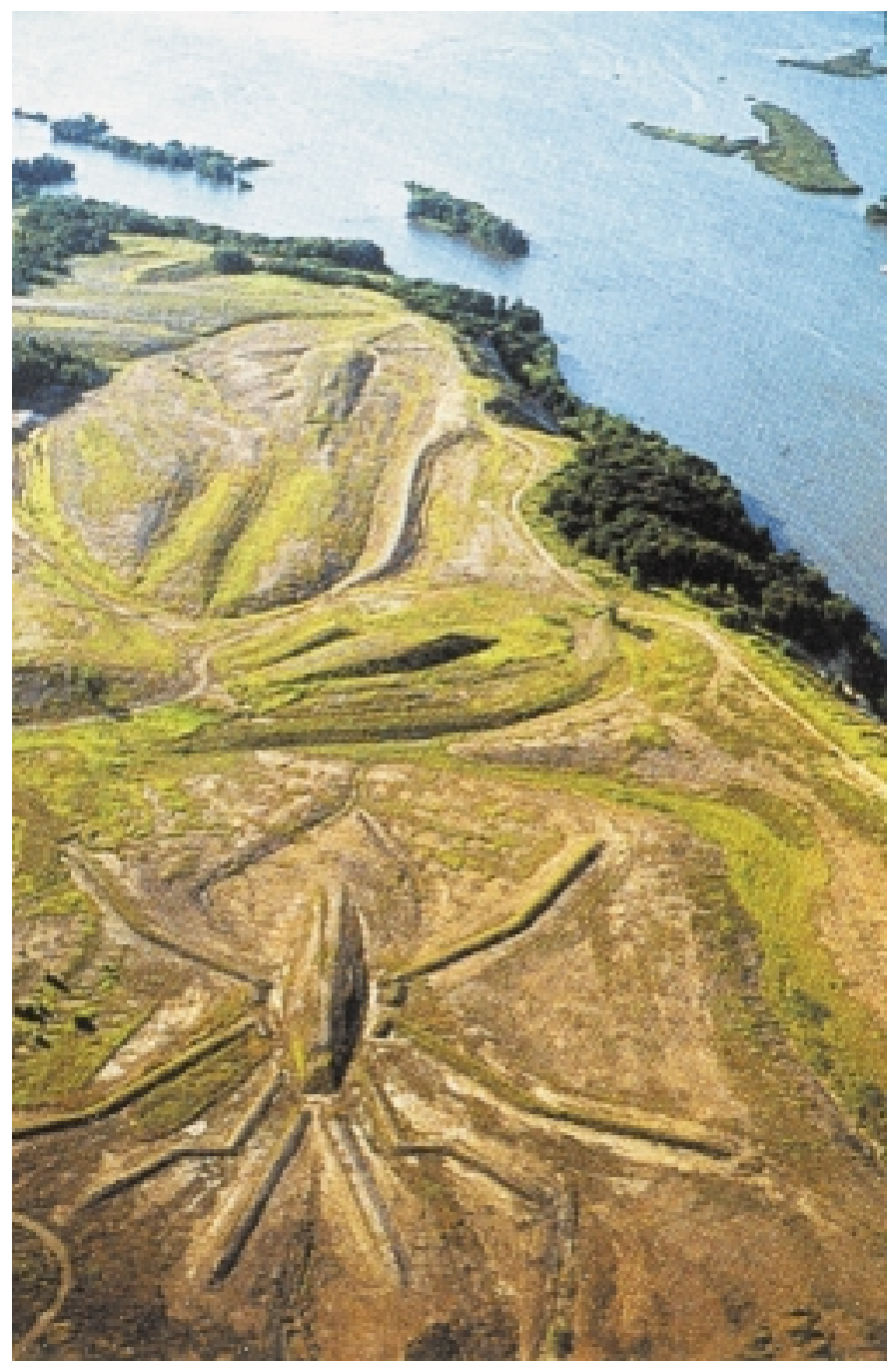

Figure 28. Water strider earthen sculpture from "Effigy Tumuli," 1983 85. Courtesy Department of Natural Resources, Buffalo Rock State Park, III.

under the section entitled "Art.” Interestingly, Heizer commented, "I don't support reclamation art sculpture projects. This is strictly art. I love mining sites. My whole family has been in the mining business" (Bourdon, 1995, p. 226). Yet, the design addresses environmental concerns for potential toxic waste while creating a public recreational facility.

\section{Conclusions}

Whether a mining site is active or abandoned, if it is in sight, it is in the mind. Given environmental concerns, an operating or reclaimed site can no longer be considered isolated from its surroundings. Site analysis of mine works needs to go beyond site-specific information and relate to the regional ecological context of the greater landscape. Permitted mine areas could be planned to link regions with continuous natural corridors, rich in plant and animal life. Only by finding preferred areas can we make use of quality material while disturbing the land as little as possible. Attitudes toward mining today are very different from those of 100 or even 50 years ago.
Cultural attitudes toward land management and mining reclamation need to catch up with the reality of the 21 st century. Failure to perceive the real demand for raw materials in an evergrowing society hinders decisions on how to manage resources and create meaningful landscapes. Optimists believe that new technologies, substitutes, and more efficient recycling will allow continued supplies of new mineral resources for society (for instance, concrete with a longer life span will be produced). Onsite recycling for construction materials offers potential lower costs and environmental sensitivity for a natural resource. Research on technology to separate drywall and wood from cementitious material needs to continue. Pessimists think that we must reduce the demand for minerals by population control and per capita consumption. The natural and built worlds yield wide ranges of experience and options. Surface mining will probably not stop - although additional regulations may be enacted.

Forums such as the 2-year study in Minnesota provide an informal, balanced setting for building relationships between competing peoples with similar problems. Planners are using landscape architects to help "enhance the native character of the created or restored site, fitting the built landscape into the natural design of the surrounding area" (Manci, 1989, p. 18). Performance bonds are already usually required to assure reclamation work. Compliance with filed reclamation plans, enforcement of reclamation acts, and addressing abandoned mines all require money. Is there a need for a State aggregate material tax (a production tax based upon the weight or volume removal of gravel) to be distributed for county road and bridge improvements or as a reserve for the restoration of abandoned pits?

Design guidelines are needed concerning ecotype plant palettes with a large gene pool, hydrologic impact in a watershed due to mines, mitigation of landscape damage (necessitating geologic research in soil structure to predetermine spoil character and best land use), construction details that reinforce the regional identity, and wetland reclamation. Research into constructed wetlands (on exhausted pits) for wastewater treatment and wildlife habitat may have great benefits for society and the Earth. Both the general public and industry must recognize that landscape is more than a "garden" and grass more than a "lawn." The public needs to understand the economic value of the aggregate industry and the industry needs to recognize the ecological, cultural, and esthetic value of an area.

An existing wealth of scientific information needs to be standardized, integrated, and presented in a usable format. An annotated list of aggregate and hard rock research and demonstration areas would be helpful. The scientist's perception of landscape should not exclude the public viewpoint. The difficult part for scientists is articulating and classifying landscape components.

Maps that make use of multiple overlays of digital datasets yield valuable information for future land-planning decisions at local levels. Landscape itself needs to be viewed as one natural and human process: it is not the case of one ruling over the other. A mining site within an urban corridor may require a different design approach from one in a wilderness area. The National Park Service has elected to close roads and add visual screens to designated sites if an environmental impact assessment determines it appropriate. Today, progressive aggregate companies recognize the value of including landscape architects early in the planning stage. 
By discovering the true landscape and understanding it, when mining occurs, we can concentrate on designing and planning the site using information on ecology and development, research and technology, culture and nature, science and art. The data may not tell us what choices to make, but it can help with wise options. Whether a geologist, biologist, landscape architect, or city planner, we all experience change in our environment. Wetlands are a geologic disturbance just as mining is a humaninduced disturbance. It appears that a definite trend is emerging towards design with greater biodiversity in mind. More wildlife, less water use, and less reliance on chemicals are expected of industry, responsible homeowners, and business. Even though the industry's bottom line may be profit and meeting legal requirements, most operators would agree that good public relations and esthetics have become an important part of business. Earth will be left for future generations with land that is degraded or improved. It is a living canvas testifying to all of our behaviors.

\section{References Cited}

American Society of Landscape Architects, no date, Visual impact assessment for highway projects: Washington, D.C., Federal Highway Administration, Department of Transportation, Contract DOTFH-11-9694, $89 \mathrm{p}$.

Anonymous, 1997, Davison Sand \& Gravel saves the woodrat: Stone Review, v. 13, no. 1 (February), p. 24.

Arnould, Marcel, 1994, The impact of quarries on the environment-The French experience, in Aggregates-Raw materials giant: Report on the 2nd International Aggregates Symposium, Erlangen, October 22-27, 1990, p. 199-207.

Ashby, W.C., ed., 1992, National register of reclamation research and demonstration areas on mined land: Carbondale, III., Southern IIlinois University at Carbondale, American Society for Surface Mining and Reclamation. Various pagination.

Associated Press, 1996, Army Corps reviews dredging applications: Collegian, May 10, 1996, Student Publications Inc., Kansas State University, Manhattan, Kans. Accessed September 12, 1997 at URL http:// www.spub.ksu.edu/issues/v100/SP/n150/ap-sanddredging9.8.html.

Austin, Peter, 1995, Unlimited restoration: Landscape Design, no. 238 (March), p. 26-28.

Blake, Peter, 1979, God's own junkyard (Second Edition): New York, Holt, Rinehart, and Winston, $160 \mathrm{p}$.

Bliss, J.D., and Page, N. J., 1994, Modeling surficial sand and gravel deposits: Nonrenewable Resources, v. 3, no. 3, p. 237-249.

Bourdon, David, 1995, Designing the Earth/The human impulse to shape nature: New York, Harry N. Abrams, Inc., 240 p.

Breining, Greg, 1996, Roads and ridges: The Minnesota Volunteer (January-February), p. 46-51.

Brinkley, John, 1997a, Is cost of Colorado growth too high?: Rocky Mountain News, April 24, p. 14A.

1997b, Strip mine oversight neglected, group says: Rocky Mountain News, August 7, p. 31A.

Canham, Rod, 1986, Scuba diving in Pennsylvania quarry: Skin Diver, v. 35 (March), p. 88.

Cappa, J.A., and Tremain, C.M., 1995, Colorado mineral and mineral fuel activity, 1995: Colorado Geological Survey Information Series 40, $23 \mathrm{p}$.

Caribbean Coastal Studies, 1997, Beach Mining, The CCS Management (Dr. B.L. Oostdam and Matt Hough), Millersville University. Accessed
September 12, 1997 at URL http://marauder.millersv.edu/ ccs/ beach.html.

Carter, R.A., 1989, Reclamation-A growing concern: Rock Products, v. 92, no. 9, p. 34-40.

1990, Reclamation grows overseas: Rock Products, v. 93, no. 2, p. 40-44.

Clay County Beach Ridges Forum, 1997a, Clay County Beach Ridges Forum for gravel mining and prairie protection-A final report: Bemidji, Minn., Minnesota Department of Natural Resources, $54 \mathrm{p}$.

1997b, Lake Agassiz Beach Ridges-A coloring book for children: St. Paul, Minn., Minnesota Department of Natural Resources, $30 \mathrm{p}$.

Colorado Senate, 1995, Colorado Land Reclamation Act for the Extraction of Construction Materials: Senate Bill 95-156, Article 32.5, 37 p.

Corner, James, and MacLean, A.S., 1996, Taking measures across the American landscape: New Haven, Conn., Yale University Press, $185 \mathrm{p}$.

Dahl, T.E., 1990, Wetlands losses in the United States 1780's to 1980's: U.S. Fish and Wildlife Service, $21 \mathrm{p}$.

Dalton, D.W., 1985, Still life in quarry: Landscape Architecture, v. 75, no. 3, p. 66-69.

Dietrich, N.L., 1990, European rehabilitation projects reflect cultural and regional diversity: Rock Products, v. 93, no. 2, p. 45-47.

Editorials, 1997, Forest Service rowing against the current on river reclamation: Telluride Daily Planet. Accessed September 11, 1997 at URL http://www.telluridegateway.com/current/edi19970304a.html.

Engler, Mira, 1995, Waste landscapes-Permissible metaphors in landscape architecture: Landscape Journal, v. 14, no. 1 (Spring), p. 11-25.

English China Clays International, 1997, ECCI environmental issues. Accessed August 25, 1997 at URL http://www.ecci.co.uk/environ/ environ.htm.

Failure Institute, 1997, I am sorry. Accessed July 23, 1999 at URL http:www.northcoast.com/ failinst/watari.htm.

Finley, Bruce, 1997, Broken vow the pits to neighbors of Boulder mine: The Denver Post, July 21, p. $1 \mathrm{~A}$.

Fong, Tillie, 1997, Council approves Vision 2020: Rocky Mountain News, March 20, p. 42A.

Franke, T.T., 1996, Making future landscapes-Defining a path to qualified sustainability: Landscape and Urban Planning, v. 35, no. 4 (September), p. 241-246.

Gerhardt, Gary, 1998, Mouse listing spurs mixed reaction: Rocky Mountain News, May 14, p. 42A.

Gladwin, D.N., and Roelle, J.E., 1997, Evaluate [Evaluation of] habitat restoration for the WREN surface mine near Fort Collins, Colorado: U.S. Geological Survey, Midcontinent Ecological Science Center. Accessed August 22, 1997 at URL http://www.mesc.nbs.gov/WRENsurface-mine.html.

Golanda, Nella, 1994, Aexoni Quarry, Glyfada, Attica, Greece, in Lancaster, Michael, ed., The new European landscape: Oxford, Butterworth-Heinemann Ltd., 162 p.

Habitat Restoration Group, 1997, Mining reclamation programs and regulatory compliance. Accessed August 25, 1997 at URL http:// www.cruizio.com/ hrg/mrprc.htm.

Hemborg, H.T., 1996, Active permitted mine operations in Colorado, 19951996: Colorado Geological Survey, Department of Natural Resources, Information Series 141, 50 p., 1 plate in pocket.

Hodder, R.L., 1977, Dry land techniques in the semiarid West, in Thames, J.L., ed., Reclamation and use of disturbed land in the Southwest: Tucson, Ariz., The University of Arizona Press, 362 p. 
House, Christine, 1995, Beauty by extraction: Landscape Design, no. 238 (March), p. 14-16.

Illinois Department of Conservation, 1997, Ancient art form recalled. Accessed October 17, 1997 at URL http://www.iit.edu/ travel/ efftxt.html.

Jellicoe, Geoffrey, and Jellicoe, Susan, 1987, The landscape of man: New York, Thames and Hudson, Inc., $400 \mathrm{p}$.

King County Arts Commission, 1979, Earthworks-Land reclamation as sculpture: Seattle, Wash., Seattle Art Museum, 71 p.

Kuennen, Tom, 1983a, Farming, wildlife are naturals for mined aggregate sites: Rock Products, v. 86, no. 7, p. 47-51.

1983b, Mine aggregate, make methane: Rock Products, v. 86, no. 9, p. 62-63.

Leccese, Michael, 1996, Little marsh on the prairie: Landscape Architecture, v. 86, no. 7 , p. $50-55$.

Lewis, Kelly, 1995, Deal with pit owner will prevent loss of significant Huron/Wendat site: The Barrie Examiner, May 15. Accessed August 25, 1997 at URL http://www.sfo.com/ denglish/wynaks/barrie.htm.

Manci, K.M., 1989, Riparian ecosystem creation and restoration-A literature summary: U.S. Fish and Wildlife Service Biological Report 89(20), $59 \mathrm{p}$.

Massie, Sue, 1985, Timeless healing at Buffalo Rock: Landscape Architecture, v. 75, no. 3 (May/June), p. 70-71.

Mencacci, M.C., and Carter, R.A., 1989, Mine it-Reclaim it-Bank it: Rock Products, v. 92, no. 11, p. 47-57.

Meyer, E.K., 1991, The public park as avante-garde (landscape) architecture-A comparative interpretation of two Parisian parks, Parc de la Villette (1983-1990) and Parc des Buttes-Chaumont (1864-1867): Landscape Journal, v. 10, no. 1 (Spring), p. 16-26.

Mills, John, Box, John, and Coppin, Nick, 1995, Natural legacies: Landscape Design, no. 238 (March), p. 23-25.

Morson, Berny, 1997, Poll shows support for growth limits: Rocky Mountain News, February 21, p. 19A.

Myers, Norman, 1990, Miracle in a lifeless pit; quarry restoration in Kenya: Whole Earth Review, no. 66 (Spring), p. 98.

National Stone Association, 1995, Environmental management guide for the aggregate industry: Washington, D.C. Various pagination.

Norman, D.K., and Lingley, W.S., Jr., 1992, Reclamation of sand and gravel mines: Washington Geology, v. 20, no. 3 (September), p. 20-31.

Oakley, Chris, 1996, Group forms to stop dredging: Student Publications Inc., Kansas State University, February 16. Accessed August 25, 1997 at URL http://www.spub.ksu.edu/ISSUES/v100/SP/n095/citygov-dredging-oakley.html.

O'Neill, D.M., 1997, Natural landscapes are leaving lawns behind. Accessed August 25, 1997 at URL http://www.1 earth.com./1e/feature.3-11.html.

Owen, O.S., and Chiras, D.D., 1995, Natural resource conservation, Sixth Edition: Englewood Cliffs, N.J., Prentice Hall, 586 p.

Priem, Shannon, 1997, An artist with a blade: Rock Products, v. 100, no. 10, p. 27-29.

Rainey, R.M., 1994, Environmental ethics and park design-A case study of Byxbee Park: Journal of Garden History, v. 14, no. 3 (Autumn), p. 171-178.
Richardson, Gordon, 1995, Selling land by the tonne: Landscape Design, no. 238 (March), p. 41-44.

Sanko, John, 1997, Crowd control: Rocky Mountain News, July 7, p. 4A.

Schaller, F.W., and Sutton, Paul, eds., 1978, Reclamation of drastically disturbed lands: Madison, Wis., American Society of Agronomy, Crop Science Society of America, and Soil Science Society of America, $742 \mathrm{p}$.

Simpson, J.W., 1985, The emotional landscape and Public Law 95-87: Landscape Architecture, v. 75, no. 3 (May/June), p. 60-63, 108-109, 112-113.

Smardon, Richard, 1989, Human perception of utilization of wetlands for waste assimilation, or how do you make a silk purse out of a sow's ear? in Hammer, D.A., ed., Constructed wetlands for wastewater treatment: Chelsea, Mich., Lewis Publishers, Inc., p. 287-295.

Smith, Bonnie, 1997, Mining operation earns award: The Sequim Gazette, July 16. Accessed August 22, 1997 at URL http:// www.sequim-gazette.com/miningoperationearnsa970716.htm.

Starnes, L.B., and Gasper, D.C., 1995, Effects of surface mining on aquatic resources in North America, in Fisheries. Accessed August 25, 1997 at URL http://www.esd.ornl.gov/societies/AFS/ps-mine.html.

Stein, Sarah, 1997, Planting Noah's garden: New York, Houghton Mifflin Company, $448 \mathrm{p}$.

Sullivan, James, 1996, Jumping from Heaven: Yankee, v. 60, no. 7, p. 32.

Swann, Peter, 1995, Planning for the future: Landscape Design, no. 238 (March), p. 11-13.

Thompson, J.W., 1989, Stones on the Pacific Rim: Landscape Architecture, v. 79, no. 2 (March), p. 86-90.

1991, Students tackle the public scale: Landscape Architecture, v. 81 , no. 11, p. $79-80$.

1996, Taming the tide: Landscape Architecture, v. 86, no. 5, p. 7481 , p. $100-102$.

Thompson, Steve, 1997, The biosolids program at the Chambers Creek Wastewater Treatment Plant. Accessed September 19, 1997 at URL http://www.co.pierce.wa.us/abtus/ourorg/pwu/envsvcs/sewer/ biosolid.htm.

Toy, T.J., and Hadley, R.F., 1987, Geomorphology and reclamation of disturbed lands: New York, Academic Press, Inc., 480 p.

Turley, William, 1995, Composting can be a profitable idea: Rock Products, v. 98 , no. 6 , p. 22-23.

U.S. Department of Energy, Weldon Spring Site Remedial Action Project, 1996, Cleanup of the Weldon Spring Quarry. Accessed October 17, 1997 at URL http://www.em.doe.gov/wssrap/quarry.html.

U.S. Geological Survey, 1997, Minerals yearbook-Area reports, Domestic 1997: Washington, D.C., U.S. Government Printing Office, 339 p.

Usher, M.B., 1978, Natural communities of plants and animals in disused quarries: Journal of Environmental Management, v. 8, p. 223-226.

West, Jim, and Block, Gene, 1994, Creating structural compatibility, Part 3: Rock Products, v. 97, no. 10, p. 50-53.

Wiedenbein, F.W., 1994, Natural succession in disused excavations and its significance for nature conservation, in Aggregates-Raw materials giant: Report on the 2nd International Aggregates Symposium, Erlangen, October 22-27, 1990, p. 227-237.

Ziegenbein, Mark, 1997, Katmai takes on a dirty job and does it right. Accessed October 8, 1997 at URL http://www.aqd.nps.gov/pubs/ yr_rvw96/chapter7/katmai.htm. 